\title{
บUisuersily
}

\section{Performance analysis of a residential heating system using borehole heat exchanger coupled with solar assisted PV/T heat pump}

Yao, J., Liu, W. J., Zhang, L., Tian, B., Dai, Y., \& Huang, M. (2020). Performance analysis of a residential heating system using borehole heat exchanger coupled with solar assisted PV/T heat pump. Renewable Energy, 160, 160-175. https://doi.org/10.1016/j.renene.2020.06.101

Link to publication record in Ulster University Research Portal

Published in:

Renewable Energy

Publication Status:

Published (in print/issue): 30/11/2020

DOI:

10.1016/j.renene.2020.06.101

Document Version

Author Accepted version

\section{General rights}

Copyright for the publications made accessible via Ulster University's Research Portal is retained by the author(s) and / or other copyright owners and it is a condition of accessing these publications that users recognise and abide by the legal requirements associated with these rights.

\section{Take down policy}

The Research Portal is Ulster University's institutional repository that provides access to Ulster's research outputs. Every effort has been made to ensure that content in the Research Portal does not infringe any person's rights, or applicable UK laws. If you discover content in the Research Portal that you believe breaches copyright or violates any law, please contact pure-support@ulster.ac.uk. 


\title{
Performance analysis of a residential heating system using borehole heat exchanger coupled with solar assisted PV/T heat pump
}

\author{
Jian YAO a, b, Wenjie LIU a, b, Lu ZHANG ${ }^{\text {a b }}$, Binshou TIAN ${ }^{\text {c }}$, Yanjun DAI *, a, b, Mingjun \\ HUANG $^{\mathrm{d}}$ \\ ${ }^{a}$ Institute of Refrigeration and Cryogenics, Shanghai Jiao Tong University, Shanghai 200240, China \\ ${ }^{b}$ Engineering Research Center of Solar Energy and Refrigeration, MOE, China \\ ${ }^{\mathrm{c}}$ Gansu Provincial Institute of Building Materials, Lanzhou 730000, Gansu, China \\ ${ }^{\mathrm{d}}$ Centre for Sustainable Technologies, School of the Built Environment, University of Ulster, Newtownabbey, \\ Northern Ireland, BT37 0QB, UK \\ *: Corresponding author: E-mail address: yjdai@sjtu.edu.cn (Yanjun DAI); Tel.: +86-21-34204358; fax: +86- \\ 21-34206814
}

\begin{abstract}
Borehole heat exchanger (BHE) is a promising method for extracting heat from the deep geothermal energy which has been widely used for residential heating in high latitude areas. The solar assisted photovoltaic/thermal (PV/T) heat pump could convert solar energy into useful heat efficiently, and could be further used to heat water from the BHE to a higher temperature level. In this paper, a residential heating system using BHE coupled with solar assisted PV/T heat pump is therefore proposed with further performance analysis. The simulation results show that a larger mass flow rate could increase the BHE's heat extract capacity but also increase the flow resistance and pump power under nominal conditions. The circulating water would not extract heat from rock-soil if the inlet temperature exceeds $48.5^{\circ} \mathrm{C}$ when mass flow rate is $12 \mathrm{~kg} / \mathrm{s}$. Furthermore, the maximum water temperature from this hybrid system could reach $40.8{ }^{\circ} \mathrm{C}$ while the solar fraction is $67.5 \%$ when the area of PV/T module is $1000 \mathrm{~m}^{2}$, solar irradiation is $600 \mathrm{~W} / \mathrm{m}^{2}$ and depth of the BHE is $2500 \mathrm{~m}$. In the meantime, the heating COP of this hybrid system could reach 7.4 and the system could operate independently without power input from electrical grid.
\end{abstract}

Keywords: Borehole heat exchanger; Solar energy; PV/T; Heat pump; Residential heating

\section{Introduction}

Nowadays, total energy consumption is constantly climbing and has brought energy and environmental crises due to the combustion of fossil fuels, such as coal and oil. The usage of clean and renewable resources is being considered and developed as an effective way to replace conventional energy resources in recent years [1]. The problem of high and inefficient energy consumption for residential heating in high latitude areas has drawn increasing attention to the community. Geothermal energy is a promising residential heating source due to its high efficiency, low energy consumption, and environmental-friendly [2-4].

Fig. 1 shows the categories and development history of the residential heating system using a borehole heat exchanger. Firstly, the ground source heat pump system is proposed to utilize shallow geothermal energy. Then the deep borehole heat exchanger is developed to avoid ecological damage from the shallow ground source heat pump. Furthermore, as shown in Fig. 1, it is seen from 
Categories 1 to 4, the combination of other renewable energy and BHE has been studied recently to improve the system performance.

As shown in Fig. 1, the shallow geothermal energy has been widely used for residential heating or hot water applications by adopting a ground source heat pump system. However, the long-term operation of the shallow ground source heat pump will make the soil temperature imbalance and affect the ecological environment. In fact, the typical geothermal gradient is about $0.03{ }^{\circ} \mathrm{C} / \mathrm{m}[5]$ which means the temperature difference of a $2500 \mathrm{~m}$ borehole could reach $75^{\circ} \mathrm{C}$, thus, the deep borehole heat exchanger has been proposed to extract heat from deep rock-soil layer to overcome the disadvantages of shallow geothermal extraction devices. For instance, Bu et al. [6] demonstrated the feasibility of extracting heat from existing abandoned oil and gas wells by using a deep borehole heat exchanger $(4000 \mathrm{~m})$. They developed a mathematical model of the BHE and found that the heat capacity of a single well could reach $454 \mathrm{~kW}$ for a geothermal gradient of $25^{\circ} \mathrm{C} / \mathrm{km}$ when the inlet velocity is $0.05 \mathrm{~m} / \mathrm{s}$. The borehole heat exchanger is the core of the system because the working fluid in BHE could extract heat from the deep ground. Many projects using BHE systems had been constructed in several countries. A $2786 \mathrm{~m}$ BHE was adopted to extract heat for domestic hot water and spacing heating in Germany while the other project used a $2500 \mathrm{~m}$ BHE in sandstone to provide heat for a building in RWTH-Aachen University [7]. In the case study of Hinton (Alberta), Hu et al. [8] revealed the potential for geothermal exploitation using borehole heat exchangers in the Western Canadian Sedimentary Basin numerically. Their simulation results show that a $3500 \mathrm{~m}$ BHE system could produce the heat of $380 \mathrm{~kW}$, and the temperature increment could reach $8.97{ }^{\circ} \mathrm{C}$ when the inlet water temperature is $20^{\circ} \mathrm{C}$ and the mass flow rate is $10 \mathrm{~kg} / \mathrm{s}$.

The BHE has different types including U-shaped, double U-shaped, W-shaped, spiral-shaped, and coaxial [9-11]. Focus on the coaxial deep borehole heat exchanger, numerous researches have been conducted recently. For instance, Renaud et al. [12] numerically simulated a deep BHE in the Krafla geothermal system. They found that the cooling perturbation near the bottom hole is shown to grow radially from 10 to $40 \mathrm{~m}$ between 1 and 10 years of production, and the calculated output power reaches up to 1.2 MW for a single well. Luo et al. [13] designed a deep coaxial BHE for harvesting geothermal energy and proposed an analytical model for thermal analysis. They demonstrated the best flow direction with annulus as an inlet in heat extraction mode and confirm the positive influence of increasing geothermal gradients towards the heat extraction. Fang et al. [14] proposed a computationally efficient numerical model for heat transfer simulation of deep borehole heat exchangers, and their results show that the heat production could reach $310 \mathrm{~kW}$ for a $2500 \mathrm{~m} \mathrm{BHE}$ when the geothermal gradient is $30^{\circ} \mathrm{C} / \mathrm{km}$ and the geothermal heat flux is $2 \mathrm{~W} / \mathrm{m} \cdot{ }^{\circ} \mathrm{C}$. For the medium-deep borehole heat exchanger, Liu et al. [15] developed a transient heat transfer model, and numerically investigated the influence of different parameters on system performance. Their simulation results indicated that the geothermal gradient affects the thermal extraction load mostly and the heat capacity has the greatest impact on the thermal effect radius. Song et al. [16] conducted a numerical analysis of the heat extraction performance of a deep coaxial borehole heat exchanger system and established an unsteady-state heat transfer model. The further study indicated that in terms of the pressure drop and thermal power, the $25 \mathrm{~m} 3 / \mathrm{h}$ is the optimal flow rate which could obtain the best thermal performance of the BHE (5000 m).

However, the temperature of outlet circulating water could not reach over $40{ }^{\circ} \mathrm{C}$ for stable, comfortable residential heating if the inlet water temperature or geothermal gradient is low. Therefore, the combinations of other heat sources (aerothermal, solar energy, etc.) and BHE [17] 
have been proposed to reach higher outlet water temperature as shown in Fig. 1 (Categories 1 to 4). For instance, Wang et al. [18] conducted a field test and numerical investigation on the heat transfer characteristics and optimized the design of a deep BHE assisted heat pump system (Category 1). Under given conditions, the results from the field test indicated that the average heat transfer capacity of every single borehole and the average COP (coefficient of performance) of the DBGSHP (deep borehole ground source heat pump) heating system were $286.4 \mathrm{~kW}$ and 4.6, respectively. The borehole heat exchanger coupled with an air source heat pump system is another method to increase outlet water temperature from BHE. Nevertheless, the deep borehole heat exchanger assisted heat pump system and borehole heat exchanger coupled with the air source heat pump system would consume high compressor power and then leads to a lower coefficient of performance.

Major studies focus on the borehole heat exchanger assisted heat pump system (Fig. 1, Category 1). In addition to the ground source heat pump system, utilization of solar energy (Fig. 1, Category 3,4) is another effective method to widen the application of the BHE coupled heat pump system [19]. As shown in Fig. 1, in the borehole heat exchanger coupled with solar collector system (Category 3), a solar flat-plat collector has been used to absorb solar heat and further heat the outlet water form BHE. For instance, Ozgener and Hepbasli [20, 21] experimentally analyzed a solar assisted ground source heat pump heating system. In their study, the heating COP of the ground source heat pump unit and the overall system are obtained to be 2.64 and 2.38 , respectively. Wang et al. [22] presented a novel hybrid solar ground source heat pump system for office building heating. For the proposed HSGSHPS, the electrical energy demand of the system could be reduced by $32 \%$ if the load circulation pump is operated based on the fan-coils rather than always-on operation. Nevertheless, the direct expansion solar assisted heat pumps could produce heat more stable compared with the solar collectors used in these systems. Thus, the combination of direct expansion solar assisted heat pumps could be a more effective and stable way to heat the outlet water from BHE for residential heating.

In this paper, a novel borehole heat exchanger coupled with a solar assisted PV/T heat pump has been proposed. The configuration of this novel hybrid system is presented in Fig. 2. A mathematical model of this hybrid system is developed and the model of BHE is validated by experiment. The performance of this hybrid system has been studied. 


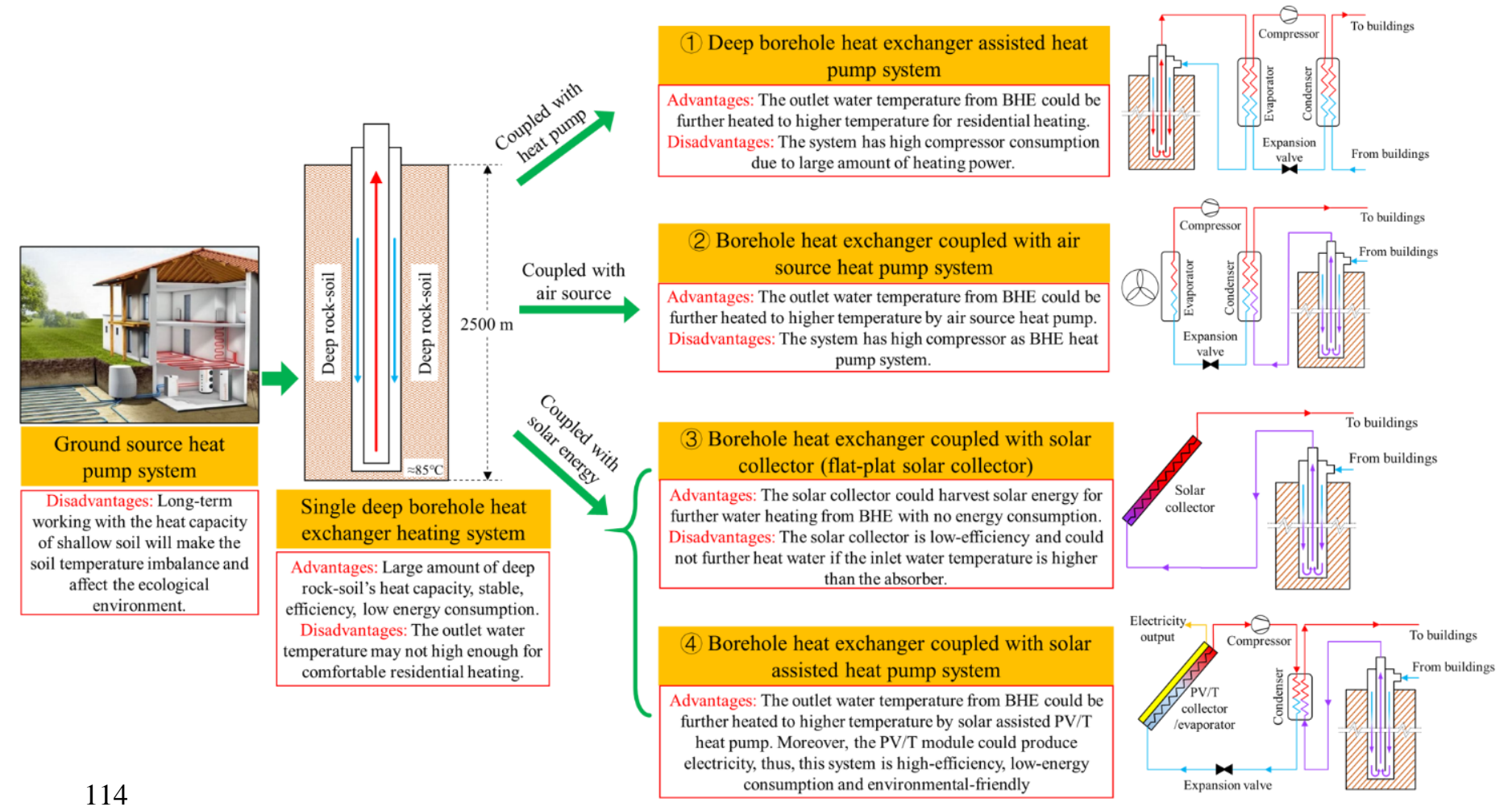

115 Fig. 1. Categories and development history of the residential heating system using borehole heat exchanger.

\section{System description}

\subsection{System configuration}

Fig. 2 shows the schematic diagram of a residential heating system using a deep borehole heat exchanger (BHE) coupled with a solar assisted PV/T heat pump. This system has three main parts: borehole heat exchanger, solar assisted PV/T heat pump, and solar power unit. The borehole heat exchanger has two coaxial pipes: inner and outer pipes to form the inlet and outlet fluid channel. The depth of the BHE is $2500 \mathrm{~m}$, and the circulating water will flow deep into the BHE's bottom and extract heat from the rock-soil. The other part is the solar assisted PV/T heat pump which could increase the water temperature from the BHE because the outlet water temperature from BHE may not meet the temperature for residential heating applications. The solar assisted PV/T heat pump system consists of PV/T collector/evaporator, compressor, condenser, and expansion valve. The $\mathrm{PV} / \mathrm{T}$ collector/evaporator could produce electricity and heat simultaneously. The solar power unit consists of MPPT solar energy controller, accumulator, and AC-DC inverter. The electricity from solar PV/T panel could be used to drive the compressor and circulating pump and the surplus electricity could output to the electrical grid.

This system can be operated with three operating modes:

(1) Borehole heat exchanger mode: The solar assisted PV/T heat pump would be stopped when the solar radiation is poor or during the night, and only the borehole heat exchanger is operated. The deep BHE will operate during day and night because it would not be influenced by the ambient conditions. Valve 1 is closed while valve 2 is opened and the circulating pump works uninterruptedly 
in this mode.

(2) Solar assisted PV/T heat pump mode: The heat from solar assisted PV/T heat pump system would meet the residential heating demand when the insolation is good enough. Therefore, the borehole heat exchanger could be turned off. Valve 1 is opened while valve 2 is closed and the electricity output by PV panel could be used to drive the compressor.

(3) Hybrid mode: If operating the BHE or solar assisted PV/T heat pump alone would not meet the residential heating demand, these two sub-systems would be operated simultaneously. Valve 1 is closed while valve 2 is opened and both the compressor and the pump would work uninterruptedly. The low-temperature water would be heated up to a middle-temperature level firstly by the borehole heat exchanger and then be heated up to a high-temperature level by solar assisted PV/T heat pump. In the meantime, the electricity output by PV panels could be used to drive the compressor and pump.

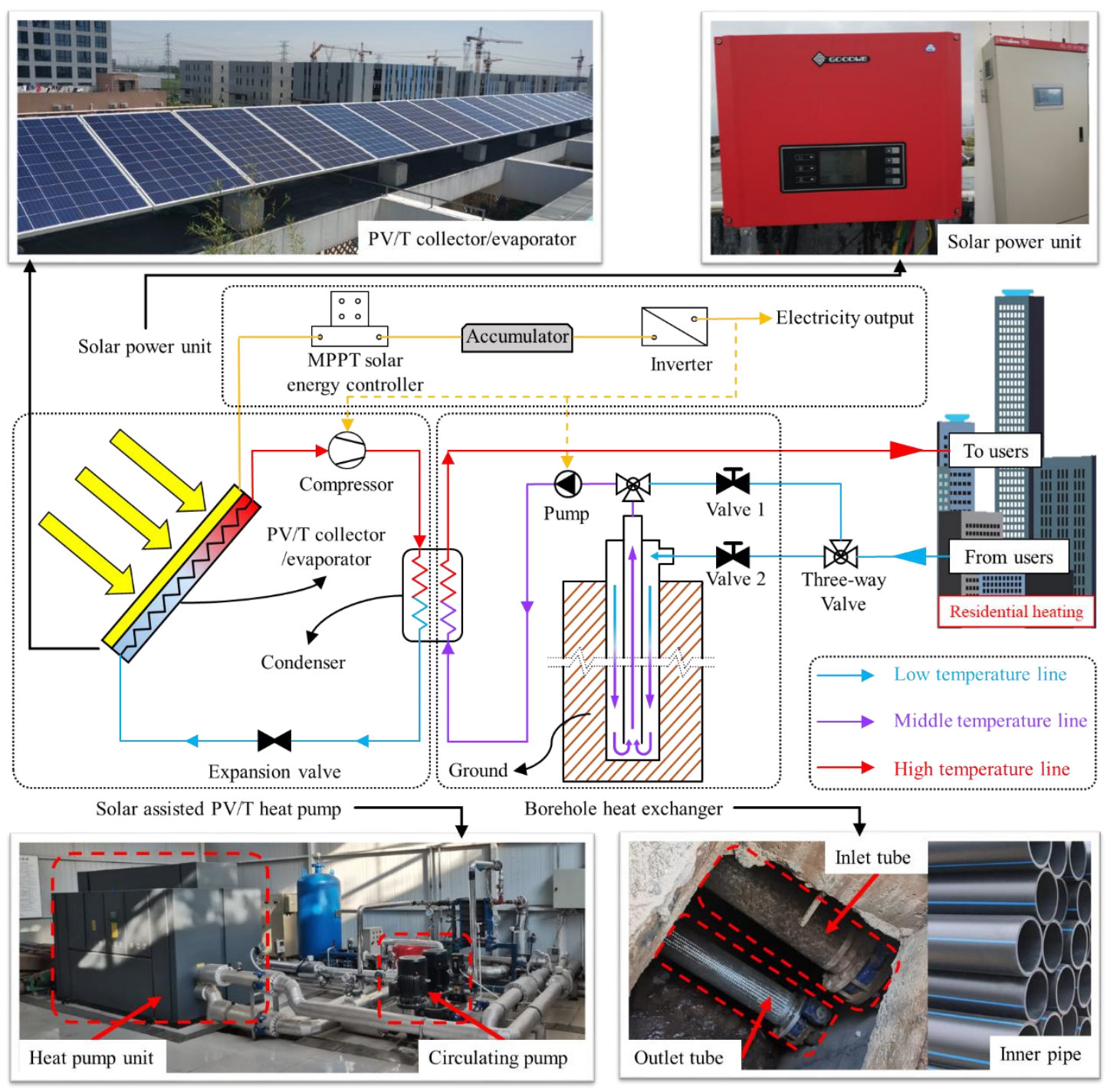

Fig. 2. Schematic diagram of a residential heating system using borehole heat exchanger coupled with a solar assisted $\mathrm{PV} / \mathrm{T}$ heat pump.

The values of the chosen parameters are taken in the field tests from the references [7, 18, 23] for initial simulation. The basic specifications for this hybrid system are listed in Table. 1. 
Table. 1. The basic specifications for the system.

\begin{tabular}{llll}
\hline Parameters & Nomenclature & Value & Unit \\
\hline Radius of construction hole & $r$ & 0.1 & $\mathrm{~m}$ \\
Inner radius of inner pipe & $r_{1}$ & 0.045 & $\mathrm{~m}$ \\
Outer radius of inner pipe & $r_{2}$ & 0.055 & $\mathrm{~m}$ \\
Inner radius of outer pipe & $r_{3}$ & 0.080 & $\mathrm{~m}$ \\
Outer radius of outer pipe & $r_{4}$ & 0.089 & $\mathrm{~m}$ \\
Number of BHE & $n$ & 1 & {$[-]$} \\
Depth of BHE & $H$ & 2500 & $\mathrm{~m}$ \\
Heat transfer fluid in BHE & {$[-]$} & water & {$[-]$} \\
Mass flow rate of circulating fluid & $m$ & 12 & $\mathrm{~kg} / \mathrm{s}$ \\
Inlet water temperature to BHE & $T_{i}$ & 30 & ${ }^{\circ} \mathrm{C}$ \\
Area of PV/T module & $A$ & 1000 & $\mathrm{~m}$ \\
Circulating pump power & $W_{\text {pump }}$ & 17.3 & $\mathrm{~kW}$ \\
Compressor power & $W_{\text {comp }}$ & 56.4 & $\mathrm{~kW}$ \\
\hline
\end{tabular}

\subsection{Performance indices}

The performance of this hybrid residential heating system is determined by its two sub-systems: borehole heat exchanger and solar assisted PV/T heat pump. The performance of the borehole heat exchanger would be influenced by the mass flow rate, inlet water temperature, depth of BHE, the radius of inner and outer pipe. The performance of solar assisted PV/T heat pump would be influenced by solar radiation intensity, area of PV/T module. Therefore, the performance indices should be defined to evaluate the system performance, which have been listed as follows. For borehole heat exchanger:

(1) $Q_{B H E}, \mathrm{~kW}$ : Heat extract capacity of BHE and it could be expressed as:

$$
Q_{B H E}=C_{p f} \cdot m_{f} \cdot\left(T_{\text {out }}-T_{\text {in }}\right)
$$

where $C_{p f}$ is the specific heat at constant pressure, $\mathrm{kJ} / \mathrm{kg} \cdot{ }^{\circ} \mathrm{C} ; m_{f}$ is the circulating water mass flow rate, $\mathrm{kg} / \mathrm{s}$;

(2) $T_{\text {in }}, T_{\text {out }},{ }^{\circ} \mathrm{C}$ : Inlet and outlet water temperature.

(3) $T_{d i f},{ }^{\circ} \mathrm{C}$ : Temperature difference between inlet and outlet circulating water and it could be calculated by:

$$
T_{\text {dif }}=T_{\text {out }}-T_{\text {in }}
$$

(4) $R$, m: Thermal effect radius of BHE and it reflects the boundary to which the BHE could extract heat form rock-soil.

(5) $C O P_{B H E}$ : Coefficient of performance of BHE and it could be defined as:

$$
C O P_{B H E}=Q_{B H E} / W_{\text {pump }}
$$

(6) $P_{d i f}, \mathrm{~kg} / \mathrm{cm}^{2}$ : Water pressure difference between inlet and outlet, and it could be calculated by: 


$$
P_{d i f}=P_{i n}-P_{o u t}
$$

where $P_{\text {in }}, P_{\text {out }}$ are the water pressures in the inlet and outlet, $\mathrm{kg} / \mathrm{cm}^{2}$.

(7) $H_{\text {res }}, \mathrm{m}$ : Corresponding water head caused by flow resistance and it could be calculated by:

$$
H_{\text {res }}=P_{\text {dif }} / \rho
$$

where $\rho$ is the water density, $\mathrm{kg} / \mathrm{m}^{3}$.

(8) $W_{\text {pump }}, \mathrm{kW}$ : Circulating pump power and it could be calculated by:

$$
W_{\text {pump }}=m_{f} \cdot g \cdot H_{\text {res }}
$$

For solar assisted $\mathrm{PV} / \mathrm{T}$ heat pump:

(1) $C O P_{h p}$ : Coefficient of performance of solar assisted PV/T heat pump and it could be defined as:

$$
C O P_{h p}=Q_{\text {cond }} / W_{\text {comp }}
$$

(2) $Q_{\text {cond }}, \mathrm{kW}$ : Condensation heat of heat pump.

(3) $W_{\text {comp }}, \mathrm{kW}$ : Compressor power.

(4) $\eta_{t h}$ : Theramal efficiency of PV/T collector and it could be calculated by:

$$
\eta_{t h}=Q_{\text {eva }} /(I \cdot A)
$$

(5) $\eta_{e}$ : Electrical efficiency of PV panels and it could be calculated by:

$$
\eta_{e}=Q_{e} /(I \cdot A)
$$

For hybrid system:

(1) $Q_{\text {heating, }}, \mathrm{kW}$ : Heating capacity and it is the sum of $Q_{B H E}$ and $Q_{c o n d}$.

(2) $C O P_{\text {sys: }}$ : Coefficient of performance of this hybrid system and it could be defined as:

$$
C O P_{\text {sys }}=\left(Q_{B H E}+Q_{\text {cond }}\right) /\left(W_{\text {pump }}+W_{\text {comp }}\right)
$$

\section{Mathematical model}

\subsection{Borehole heat exchanger}

As shown in Fig. 2, the borehole heat exchanger is an important component of this hybrid heating system and its physical model has been presented in detail in Fig. 3. This coaxial borehole heat exchanger has a concentric structure and consists of inner and outer pipes. Moreover, the gap between inner and outer pipes is the inlet fluid channel while the inner pipe is the outlet fluid channel.

An analytical method was used to solve the heat transfer model of the borehole heat exchanger and the following assumptions were made to simplify the analysis:

1. The ground has homogeneous properties.

2. The ground thermal and physical properties are constant during system operation.

3. Underground water flow and the effect of groundwater were not considered.

4. The heat capacities of inner and outer pipes were neglected and the heat transfer state was considered steady.

5. Ground temperature at far boundary remains constant. 
6. The axle wire of the borehole heat exchanger was considered as an adiabatic boundary.

7. The longitudinal heat transfer process was neglected.

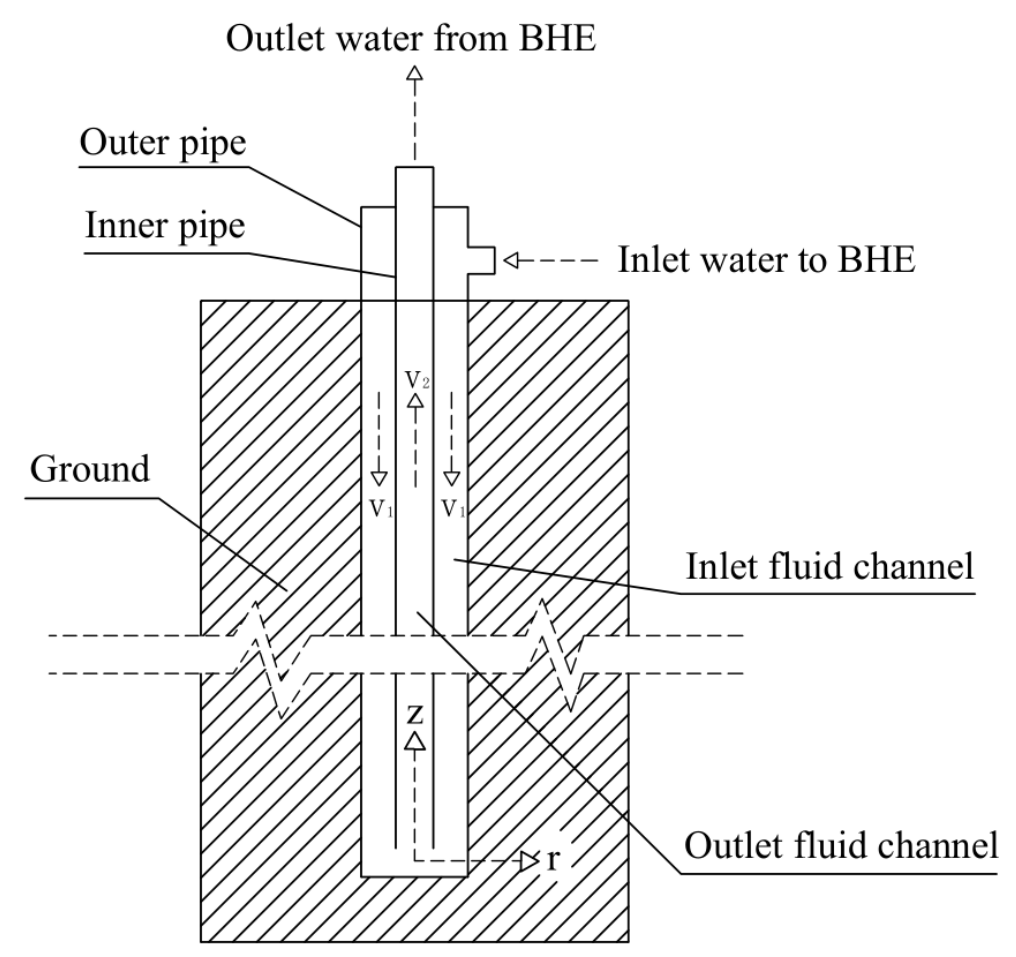

Fig. 3. Cross-section view of a deep borehole heat exchanger physical model.

According to the above-mentioned assumptions, the heat transfer model of a BHE differential unit, which is shown in Fig. 4, has been developed. The height of this BHE unit is $d z$ and this unit could be separated into five units: outlet fluid differential unit, inner pipe differential unit, inlet fluid differential unit, outer pipe differential unit, and ground differential unit. The heat transfer process of each unit has been detailed in Fig. 3 while the coordinate system is established in Fig. 4, and the origin of the coordinate is the bottom of the BHE. 


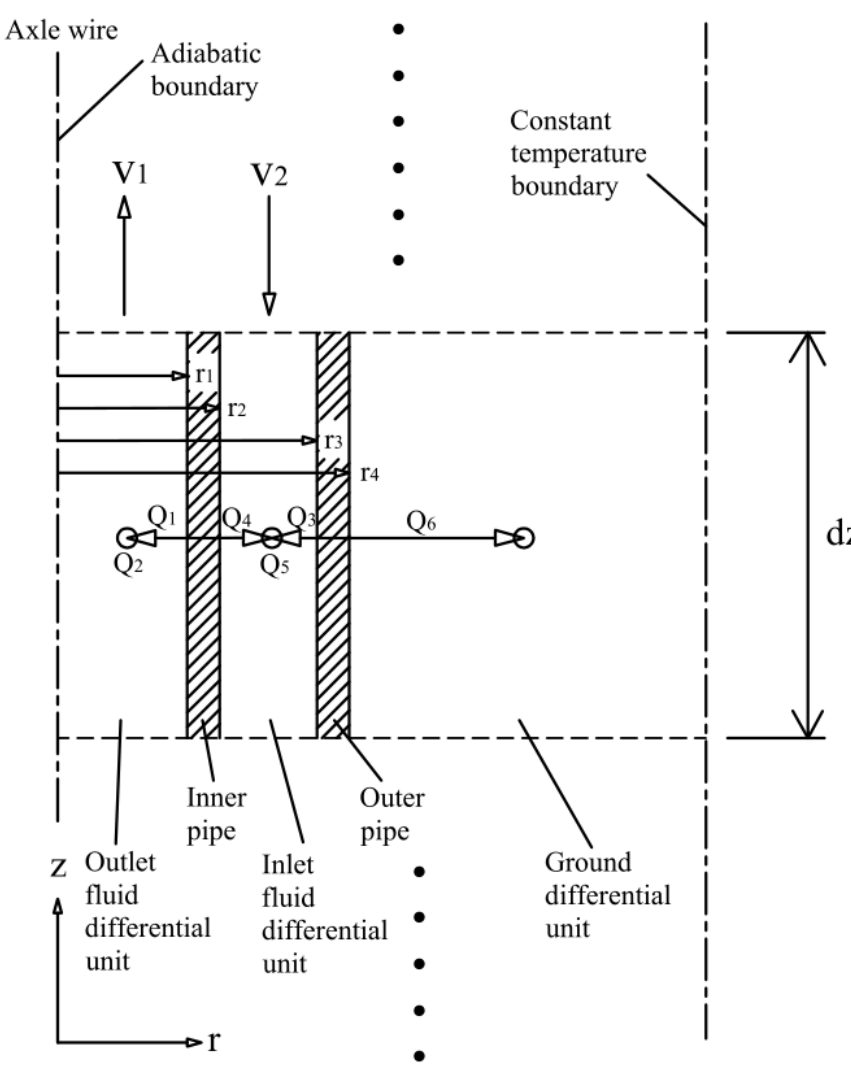

Q1: Heat transfer rate from inlet fluid differential unit to outlet fluid differential unit

Q2: Heat increment of outlet fluid differential unit

Q3: Heat transfer rate from outer pipe to inlet fluid differential unit

Q4: Heat transfer rate from outlet fluid differential unit to inlet fluid differential unit

Q5: Heat increment of inlet fluid differential unit

Q6: Heat transfer rate from outer pipe to ground differential unit

Fig. 4. Heat transfer model of a BHE differential unit.

The heat transfer rate from inlet fluid differential unit to outlet fluid differential unit through the inner pipe is $Q_{l}$ which can be calculated by [24]:

$$
Q_{1}=\frac{2 \pi d z\left(T_{f_{2}}-T_{f_{1}}\right)}{\frac{1}{\alpha_{1} r_{1}}+\frac{1}{k_{1}} \ln \frac{r_{2}}{r_{1}}+\frac{1}{\alpha_{2} r_{2}}}=\frac{2 \pi d z\left(T_{f_{2}}-T_{f_{1}}\right)}{R}
$$

where $t_{f l}$ and $t_{f l}$ are the outlet and inlet water temperatures, respectively; $\alpha_{l}$ is the convective heat transfer coefficient between outlet water and inner pipe; $\alpha_{2}$ is the convective heat transfer coefficient between inlet water and inner pipe; $k_{l}$ is the thermal conductivity of inner pipe; $r_{l}$ to $r_{4}$ are the inner and outer radiuses of inner and outer pipes; $R$ is the entire thermal resistance between outlet water and inlet water.

The heat gain of outlet fluid differential unit can be expressed as:

$$
Q_{2}=\rho_{f} C_{p f} \frac{\partial T_{f_{1}}}{\partial z} d z \cdot \pi r_{1}^{2} v_{1}
$$

where $\rho_{f}$ is the density of water; $C_{p f}$ is the specific heat at constant pressure; $v_{l}$ is the outlet velocity of the water.

According to the conservation of energy, all the heat transferred from other differential units to outlet differential unit should equal to the increment of the outlet fluid differential unit:

$$
Q_{1}=Q_{2}
$$

Eliminate $\pi d z$ from the formula and then the governing equation for the outlet fluid differential 
unit can be expressed as:

$$
\frac{2}{R}\left(T_{f_{2}}-T_{f_{1}}\right)-\rho_{f} C_{p f} \frac{\partial T_{f_{1}}}{\partial z} r_{1}^{2} v_{1}=0
$$

The heat transfer rate from the outer pipe to the inlet fluid differential unit can be calculated by:

$$
Q_{3}=\frac{2 \pi d z \cdot\left(T_{3}-T_{f_{2}}\right)}{\alpha_{3} r_{3}}
$$

where $t_{3}$ is the temperature of the outer pipe; $\alpha_{3}$ is the convective heat transfer coefficient between the outlet water and the outer pipe;

According to the assumptions, only the radial heat transfer process is considered, thus:

$$
Q_{4}=-Q_{1}
$$

$$
Q_{6}=-Q_{3}
$$

The heat gain of the inlet fluid differential unit can be expressed as:

$$
Q_{5}=-\rho_{f} C_{p f} \pi\left(r_{3}^{2}-r_{2}^{2}\right) v_{2} \cdot \frac{\partial T_{f_{2}}}{\partial z} \cdot d z
$$

According to the conservation of energy, this equation can be obtained:

$$
Q_{3}+Q_{4}=Q_{5}
$$

Then submit $Q_{3}, Q_{4}, Q_{5}$ into the equation, and the governing equation for the inlet fluid differential unit can be expressed as:

$$
2 \alpha_{3}\left(T_{3}-T_{f_{2}}\right)+\frac{2\left(T_{f_{1}}-T_{f_{2}}\right)}{R}=-\rho_{f} c_{p f}\left(r_{3}^{2}-r_{2}^{2}\right) v_{2} \frac{\partial T_{f_{2}}}{\partial z}
$$

The boundary conditions for solving this heat transfer model of BHE are obtained from reference [15] and listed in Table. 2.

Table. 2. Boundary conditions for the BHE differential unit.

\begin{tabular}{ccc}
\hline Position & Expression & Equation \\
\hline Fluid inlet & $Z=H$ & $T_{f 2}=T_{i}$ \\
Bottom of the BHE & $Z=0$ & $T_{f 2}=T_{f 1}$ \\
Axle wire & $r=0$ & $Q=0$ \\
Far ground boundary & $r \rightarrow \infty$ & $T_{\text {ground }}=T_{\infty}$ \\
\hline
\end{tabular}

The properties of the borehole heat exchanger listed in Table. 3 are selected as typical values for initial simulation according to the references $[5,7,18,23]$. 
Table. 3. Properties of the borehole heat exchanger.

\begin{tabular}{llll}
\hline Parameters & Nomenclature & Value & Unit \\
\hline specific heat at constant pressure of water & $C_{p f}$ & 4.2 & $\mathrm{~kJ} / \mathrm{kg} \cdot{ }^{\circ} \mathrm{C}$ \\
Inner pipe material & {$[-]$} & PE & {$[-]$} \\
Thermal conductivity of inner pipe & $k_{l}$ & 0.4 & $\mathrm{~W} / \mathrm{m} \cdot{ }^{\circ} \mathrm{C}$ \\
Outer pipe material & {$[-]$} & Seamless & {$[-]$} \\
& & stell J55 & \\
Thermal conductivity of outer pipe & $k_{2}$ & 41 & $\mathrm{~W} / \mathrm{m} \cdot{ }^{\circ} \mathrm{C}$ \\
Thermal conductivity of the ground & $k_{g}$ & 3.49 & $\mathrm{~W} / \mathrm{m} \cdot{ }^{\circ} \mathrm{C}$ \\
Depth of BHE & $H$ & 2500 & $\mathrm{~m}$ \\
Mass flow rate of circulating water & $m$ & 12 & $\mathrm{~kg} / \mathrm{s}$ \\
Ambient temperature & $T_{a}$ & 10 & ${ }^{\circ} \mathrm{C}$ \\
Ground surface temperature & $T_{u p}$ & 10 & ${ }^{\circ} \mathrm{C}$ \\
Geothermal gradient & $T_{g}$ & 0.03 & ${ }^{\circ} \mathrm{C} / \mathrm{m}$ \\
Inlet water temperature to BHE & $T_{i}$ & 30 & ${ }^{\circ} \mathrm{C}$ \\
\hline
\end{tabular}

\subsection{PV/T collector/evaporator}

Fig. 5 shows the heat loss and physical model of a typical PV/T collector/evaporator. A portion of the solar radiation can be converted to electricity directly by PV panels while the PV panel would absorb the rest of solar radiation and convert it to heat. The PV/T technology could output both electricity and heat simultaneously and is suitable for heating applications.

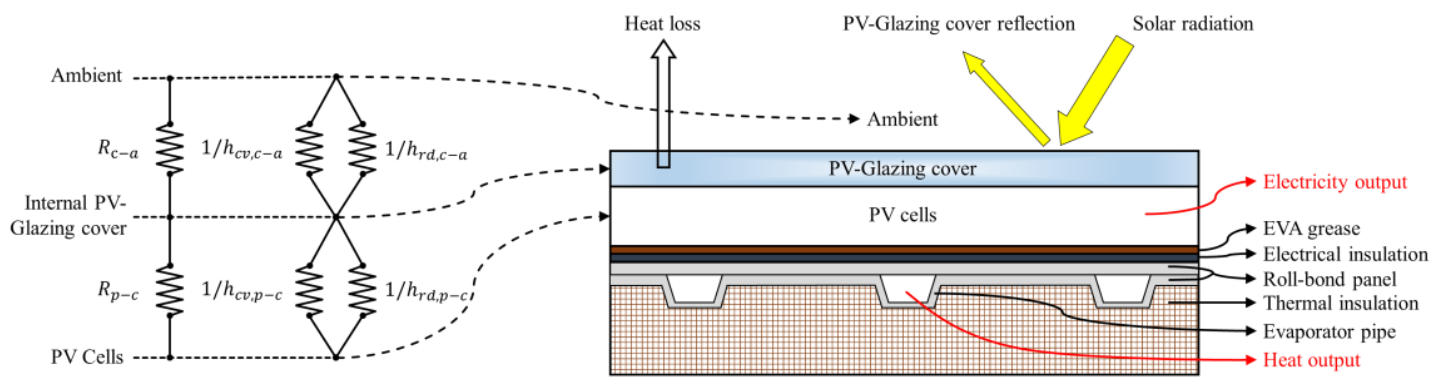

Fig. 5. Heat loss and physical model of PV/T collector/evaporator [25].

The electricity output by PV panels could be expressed as:

$$
Q_{e}=A \cdot I \cdot \tau_{g, p v} \cdot \alpha_{p} \cdot \beta_{p} \cdot \eta_{e}
$$

where $A$ is the area of PV/T module; $I$ is the solar radiation intensity; $\tau_{g, p v}$ is the transmittances of the PV-glazing cover; $a_{p}$ is the absorption ratio of the PV panels; $\beta_{p}$ is the packing factor of $\mathrm{PV}$ panels; $\eta_{e}$ is the PV panels' efficiency which can be calculated by [26]:

$$
\eta_{e}=\eta_{r c} \cdot\left[1-\beta_{p v} \cdot\left(T_{p}-T_{r c}\right)\right]
$$

$\eta_{r c}$ is the reference photovoltaic efficiency value of PV panels at $T_{r c}=298 \mathrm{~K}, \eta_{r c}=0.18$; $\beta_{p v}$ is the temperature coefficient $(1 / \mathrm{K})$ of PV cell efficiency, $\beta_{p v}=0.0045$ [26].

The heat absorbed by the PV/T module can be calculated by [27]: 


$$
Q_{e v a}=A \cdot F^{\prime} \cdot\left[\left(\tau_{g, p v} \cdot \alpha_{p} \cdot \beta_{p}\right) \cdot I \cdot\left(1-\eta_{\mathrm{e}}\right)-U_{L} \cdot\left(T_{w}-T_{a}\right)\right]
$$

where $F^{\prime}$ is the efficiency factor; $T_{w}$ is the average refrigerant temperature in the $\mathrm{PV} / \mathrm{T}$ collector/evaporator; $T_{a}$ is the ambient temperature; $U_{L}$ is the overall heat loss coefficient which can be expressed as:

$$
U_{L}=\left[1 /\left(h_{c v, p-c}+h_{r d, p-c}\right)+1 /\left(h_{c v, c-a}+h_{r d, c-a}\right)\right]^{-1}
$$

$h_{c v, p-c}$ and $h_{r d, p-c}$ are the convective and radiative heat-transfer coefficients between PV panels and glass cover; $h_{c, c-a}$ and $h_{r d, c-a}$ are the convective and radiative heat-transfer coefficients between the glass cover and ambient.

The characteristics of different PV/T layers are obtained from the reference [25] and listed in Table. 4.

Table. 4. Characteristics of different PV/T layers [25].

\begin{tabular}{llll}
\hline Parameters & Nomenclature & Value & Unit \\
\hline Thickness of PV-glazing cover & $\delta_{g, p v}$ & 1 & $\mathrm{~mm}$ \\
Emissivity of PV-glazing cover & $\varepsilon_{c}$ & 0.84 & {$[-]$} \\
Transmissivity of PV-glazing cover & $\tau_{g, p v}$ & 0.9 & {$[-]$} \\
Thickness of PV cells & $\delta_{p v}$ & 0.3 & $\mathrm{~mm}$ \\
Emissivity of PV cells & $\varepsilon_{p}$ & 0.96 & {$[-]$} \\
Absorptance of PV cells & $a_{p}$ & 0.85 & {$[-]$} \\
Thermal conductivity of PV cells & $\kappa_{p}$ & 203 & $\mathrm{~W} / \mathrm{m} \cdot{ }^{\circ} \mathrm{C}$ \\
Absorptance of PV baseboard & $a_{b}$ & 0.8 & {$[-]$} \\
Thickness of EVA grease & $\delta_{E V A}$ & 0.5 & $\mathrm{~mm}$ \\
Thermal conductivity of EVA grease & $\kappa_{E V A}$ & 0.311 & $\mathrm{~W} / \mathrm{m} \cdot{ }^{\circ} \mathrm{C}$ \\
Thickness of electrical insulation & $\delta_{e i}$ & 0.5 & $\mathrm{~mm}$ \\
Thermal conductivity of electrical insulation & $\kappa_{e i}$ & 0.15 & $\mathrm{~W} / \mathrm{m} \cdot{ }^{\circ} \mathrm{C}$ \\
Electrical insulation material & {$[-]$} & Tedlar & {$[-]$} \\
Packing factor & $\beta_{p}$ & 1 & {$[-]$} \\
Length of PV/T collector/evaporator & $L$ & 2.0 & $\mathrm{~m}$ \\
Width of PV/T collector/evaporator & $W$ & 1.0 & $\mathrm{~m}$ \\
Area of the PV/T collector/evaporator & $A$ & 2.0 & $\mathrm{~m}{ }^{2}$ \\
Thermal conductivity of roll-bond panel & $\kappa_{r b}$ & 151 & $\mathrm{~W} / \mathrm{m} \cdot{ }^{\circ} \mathrm{C}$ \\
Thickness of roll-bond panel pipe & $\delta_{r b}$ & 1 & $\mathrm{~mm}$ \\
Refrigerant type & $r e f$ & $\mathrm{R} 134 \mathrm{a}$ & {$[-]$} \\
\hline
\end{tabular}

\subsection{Compressor}

The refrigerant mass flow rate $m_{\text {ref }}$ in the thermodynamic cycle can be calculated by [28]:

$$
m_{\text {ref }}=\lambda \cdot V_{t h} / v_{\text {suc }}
$$

where the $\lambda$ is the compressor volumetric efficiency, $V_{t}$ is the theoretical displacement volume of the compressor, $v_{s u c}$ is the specific volume of the refrigerant in the suction period. 


$$
P_{\text {com }}=m_{\text {ref }} \cdot\left(h_{\text {dis }}-h_{\text {suc }}\right) / \eta_{\text {ele }}
$$

311 where $h_{d i s}$ and $h_{s u c}$ are the enthalpies of discharged and suction refrigerant in the compressor, respectively; $\eta_{\text {ele }}$ is the efficiency of the compressor.

The refrigerant vapor through the compressor is isentropic, thus, the equation can be expressed as:

$$
T_{\text {dis }} / T_{\text {suc }}=\left(p_{\text {dis }} / p_{\text {suc }}\right)^{(\chi-1) / \chi}
$$

where the $\chi$ is the polytropic index of refrigerant; $p_{d i s}$ and $p_{s u c}$ are the pressure of discharged and suction refrigerant in the compressor, respectively.

\subsection{Condenser}

The heat transferred by refrigerant vapor to condenser can be expressed as:

$$
Q_{\text {cond }}=m_{\text {ref }} \cdot\left(h_{\text {cond, in }}-h_{\text {cond }, \text { out }}\right)
$$

where $h_{\text {cond,in }}$ and $h_{\text {cond,out }}$ are the inlet refrigerant enthalpy and outlet refrigerant enthalpy through the condenser, respectively.

In this hybrid system, the condensation heat could be used to heat the outlet water from the borehole heat exchanger for residential heating applications.

\subsection{Expansion valve}

The refrigerant fluid passes rapidly through the expansion valve, thus, this process is practically considered as adiabatic and isenthalpic in the steady stage. Consequently, the enthalpy of inlet and outlet refrigerant through expansion valve are considered the same which can be expressed as:

$$
h_{\text {expan }, \text { in }}=h_{\text {expan }, \text { out }}
$$

where $h_{\text {expan,in }}$ and $h_{\text {expan,out }}$ are the inlet refrigerant enthalpy and outlet refrigerant enthalpy through the expansion valve, respectively.

\section{Experimental validation}

The residential heating system using BHE coupled with solar assisted PV/T heat pump is first proposed in this paper and the experiments of this kind of hybrid system have not been reported. In this hybrid system, the borehole heat exchanger and solar assisted PV/T heat pump are arranged in parallel to heat the circulating water. Thus, these two systems could be validated independently. The mathematical model of the solar assisted PV/T heat pump has been validated in Yao's paper [25]. Therefore, in this section, the experimental results from reference [18] have been used to verify the mathematical model of the BHE system. The experimental setup and properties of the borehole heat exchanger have been listed in Table. 5. 
Table. 5. Experimental setup and properties of the borehole heat exchanger [18].

\begin{tabular}{llll}
\hline Parameters & Nomenclature & Value & Unit \\
\hline Outer diameter of inner pipe & $d_{2}$ & 0.11 & $\mathrm{~m}$ \\
Thickness of inner pipe & $\delta_{1}$ & 0.01 & $\mathrm{~m}$ \\
Outer diameter of outer pipe & $d_{4}$ & 0.1778 & $\mathrm{~m}$ \\
Thickness of inner pipe & $\delta_{2}$ & 0.00919 & $\mathrm{~m}$ \\
Circulating fluid & {$[-]$} & Water & {$[-]$} \\
Inner pipe material & {$[-]$} & HDPE & {$[-]$} \\
Thermal conductivity of inner pipe & $k_{I}$ & 0.45 & $\mathrm{~W} / \mathrm{m} \cdot{ }^{\circ} \mathrm{C}$ \\
Outer pipe material & {$[-]$} & Seamless & {$[-]$} \\
& & stell J55 & \\
Depth of BHE & $H$ & 2000 & $\mathrm{~m}$ \\
Inlet velocity of circulating water & $v_{\text {in }}$ & 0.7 & $\mathrm{~m} / \mathrm{s}$ \\
Mass flow rate of circulating water & $m$ & 7.32 & $\mathrm{~kg} / \mathrm{s}$ \\
\hline
\end{tabular}

The experimental and simulated inlet water temperature, inlet velocity of circulating water, outlet water temperature form BHE, and heat extract capacity under typical conditions have been listed in Table. 6. It can be found that the average outlet water temperature from BHE and the heat extract capacity are $26.6^{\circ} \mathrm{C}$ and $286.4 \mathrm{~kW}$, respectively, when the average inlet water temperature to BHE is $17.6{ }^{\circ} \mathrm{C}$ and the inlet velocity is $0.7 \mathrm{~m} / \mathrm{s}$. The simulation is conducted at the same inlet water temperature and inlet velocity. The simulation results show that the outlet water temperature from BHE is $26.3{ }^{\circ} \mathrm{C}$ while the heat extract capacity is $267.5 \mathrm{~kW}$. Compared with the experimental results, the relative errors of outlet water temperature from BHE and heat extract capacity are $3.0 \%$ and $6.6 \%$, respectively. Both relative errors are under $7 \%$ which means the simulation results show good agreement with the experimental results.

Table. 6. Comparison between experimental and simulated results under typical conditions.

\begin{tabular}{lllll}
\hline Item & $\begin{array}{l}\text { Inlet water } \\
\text { temperature to } \\
\text { BHE }\left({ }^{\circ} \mathrm{C}\right)\end{array}$ & $\begin{array}{l}\text { Inlet velocity of } \\
\text { circulating water } \\
(\mathrm{m} / \mathrm{s})\end{array}$ & $\begin{array}{l}\text { Outlet water } \\
\text { temperature from } \\
\text { BHE }\left({ }^{\circ} \mathrm{C}\right)\end{array}$ & $\begin{array}{l}\text { Heat extract } \\
\text { capacity } \\
(\mathrm{kW})\end{array}$ \\
\hline Experimental results & 17.6 & 0.7 & 26.6 & 286.4 \\
Simulation results & 17.6 & 0.7 & 26.3 & 267.5 \\
Relative error & {$[-]$} & {$[-]$} & $3.3 \%$ & $6.6 \%$ \\
\hline
\end{tabular}

To further ensure the reliability of the mathematical model, the error analyses of experimental and simulated outlet temperatures changing with inlet velocity and inlet temperature have been conducted, and the results have been shown in Fig. 6. The green dots represent the experimental outlet temperatures under different conditions. Fig. 6(a) shows the decreasing trend of outlet temperature with the increase of inlet velocity when the inlet temperature is $17^{\circ} \mathrm{C}$, and the simulated outlet temperature reduces linearly from $32.4{ }^{\circ} \mathrm{C}$ to $24.2{ }^{\circ} \mathrm{C}$ when inlet velocity varies from $0.3 \mathrm{~m} / \mathrm{s}$ to $1.3 \mathrm{~m} / \mathrm{s}$. The maximum relative error $(2.66 \%)$ is obtained when the inlet velocity is $0.7 \mathrm{~m} / \mathrm{s}$ while the average relative error is $1.67 \%$. As shown in Fig. $6(\mathrm{~b})$, the outlet temperature increases with the increase of inlet temperature $\left(13{ }^{\circ} \mathrm{C}\right.$ to $\left.23^{\circ} \mathrm{C}\right)$ when the inlet velocity is $0.7 \mathrm{~m} / \mathrm{s}$. The peak value of the simulated outlet temperature is $32.2{ }^{\circ} \mathrm{C}$ while the experimental outlet temperature is $33.0{ }^{\circ} \mathrm{C}$ 
when the inlet temperature is $23{ }^{\circ} \mathrm{C}$, and its corresponding relative error is $-2.21 \%$. The maximum relative error is $2.94 \%$, which occurs when the inlet temperature is $13{ }^{\circ} \mathrm{C}$, while the experimental and simulated outlet temperatures are $25.4{ }^{\circ} \mathrm{C}$ and $26.2{ }^{\circ} \mathrm{C}$, respectively. The average relative error is $1.93 \%$ in this case. All the relative errors of experimental and simulated outlet temperatures under different conditions are within $\pm 5 \%$, which means the simulation results show good agreement with the experimental results. Therefore, the proposed mathematical model of BHE is considered reliable for further performance analysis.

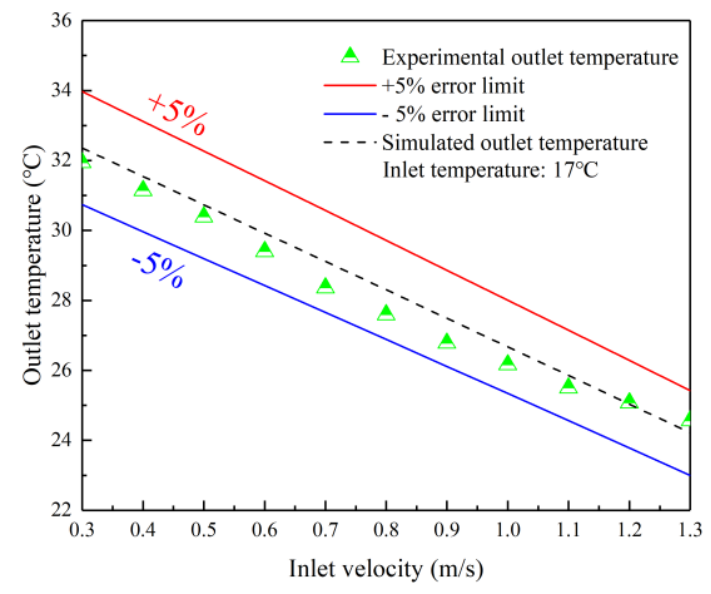

(a)

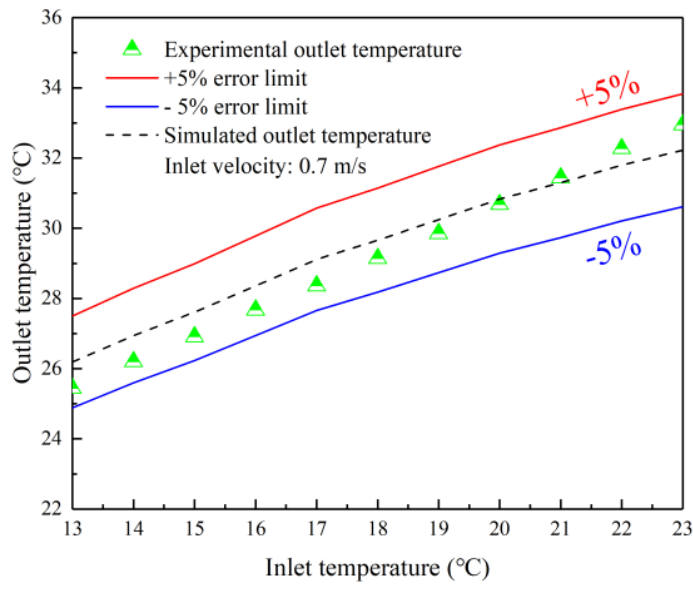

(b)

Fig. 6. Error analyses of (a) experimental and simulated outlet temperatures changing with inlet velocity. (b) experimental and simulated outlet temperatures changing with inlet temperature.

\section{Performance analysis}

After the validation of the mathematical model, further performance analysis of the proposed residential heating system using a borehole heat exchanger coupled with a solar assisted $\mathrm{PV} / \mathrm{T}$ heat pump has been conducted. The effects of the system operating conditions (mass flow rate, inlet water temperature, thermal effect radius, solar radiation intensity) and physical structure parameters (inner and outer pipes' diameters, area of PVT module) on system performance have been numerically investigated in this section. Moreover, the feasibility analysis has also been conducted to reveal the merits of this hybrid system.

\subsection{Mass flow rate}

The influence of mass flow rate instead of inlet velocity on system performance is analyzed in this sub-section. That is because the circulating water is pumped by the circulating pump, and the most important parameter of the pump is the mass flow rate. In addition, different mass flow rate determines different types of circulating pump. However, the inlet velocity needs to be calculated by the mass flow rate and the inlet area. Therefore, it is more reasonable to select the mass flow rate as a variable parameter. The influence of circulating water mass flow rate varying from $8 \mathrm{~kg} / \mathrm{s}$ to 16 $\mathrm{kg} / \mathrm{s}$ on water temperature at different positions has shown in Fig. 7. Here the inlet water temperature to BHE is $20^{\circ} \mathrm{C}$ and the depth of BHE is $2500 \mathrm{~m}$. The outlet water temperature increases with the decrease of mass flow rate and the outlet water temperature could reach the peak value which is $27.4{ }^{\circ} \mathrm{C}$ when the mass flow rate is $8 \mathrm{~kg} / \mathrm{s}$. That is because a lower mass flow rate would lead to a 
lower inlet velocity which means the circulating water could extract heat from rock-soil sufficiently in the annular fluid channel. The temperature differences between outlet and inlet water are $7.4^{\circ} \mathrm{C}$, $6.3{ }^{\circ} \mathrm{C}, 5.4{ }^{\circ} \mathrm{C}, 4.7^{\circ} \mathrm{C}$, and $4.2^{\circ} \mathrm{C}$ when the mass flow rates are $8 \mathrm{~kg} / \mathrm{s}, 10 \mathrm{~kg} / \mathrm{s}, 12 \mathrm{~kg} / \mathrm{s}, 14 \mathrm{~kg} / \mathrm{s}$ and $16 \mathrm{~kg} / \mathrm{s}$, respectively. A higher outlet water temperature is more suitable for residential heating, from this aspect, a lower inlet mass flow rate is better for system performance. However, the heat extract capacity is determined by the mass flow rater and temperature difference as shown in Eq. 1. Thus, the heat extract capacity and system COP should be calculated to evaluate the system performance.

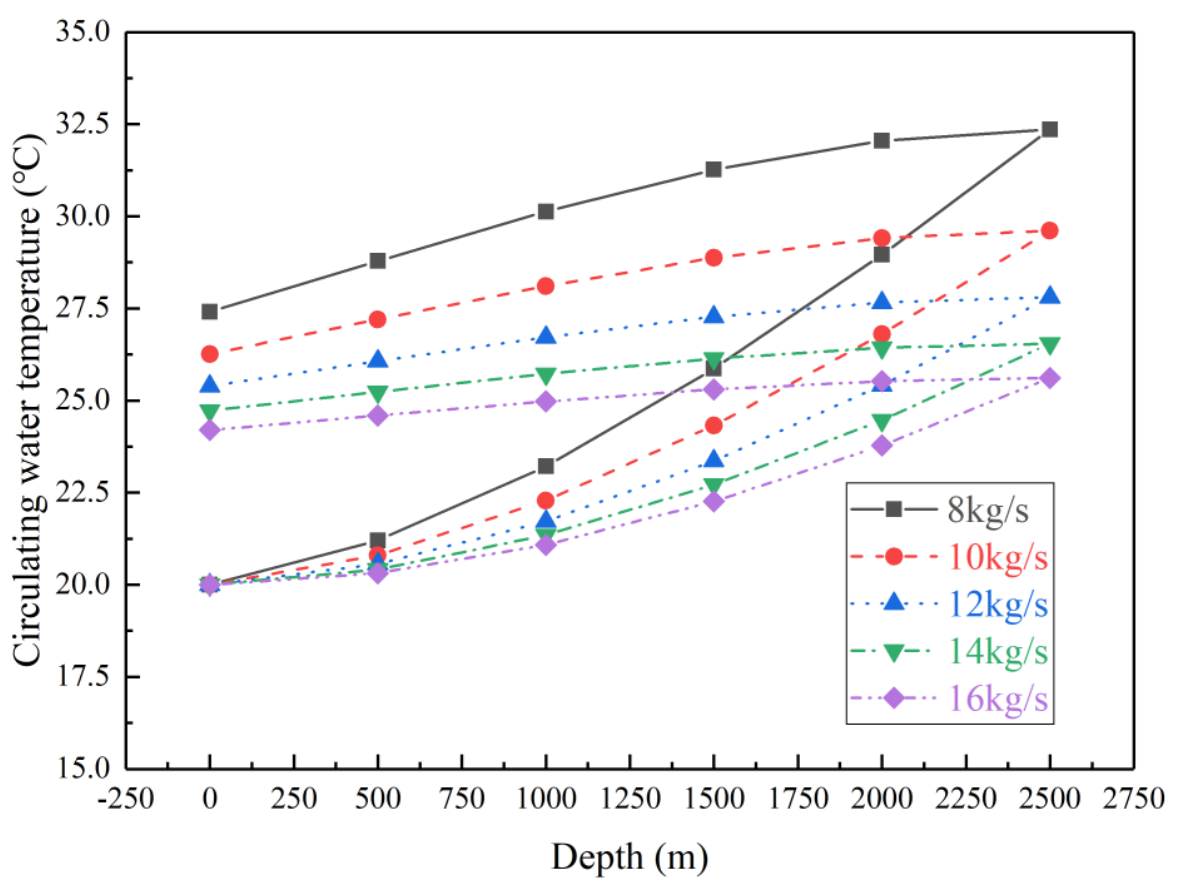

Fig. 7. Influence of mass flow rate on circulating water temperature at different positions.

Fig. 8 shows the influence of mass flow rate on the temperature difference between outlet and inlet water, heat extract capacity, and $C O P_{B H E}$. The heat extract capacity increases and the BHE system COP, as well as the temperature difference, decreases with the increase of mass flow rate. For instance, the temperature increment of $8 \mathrm{~kg} / \mathrm{s}$ is the highest $\left(7.4^{\circ} \mathrm{C}\right)$ but the heat extract capacity under this condition is the lowest $(248.8 \mathrm{~kW})$. The heat extract capacity could reach the peak value which is $282.5 \mathrm{~kW}$ while the BHE system COP is 7.3 when the mass flow rate is $16 \mathrm{k} / \mathrm{s}$. Compared with a conventional heating system like an air conditioner, the borehole heat exchanger is more efficient, low-energy consumption, and environmental-friendly. 


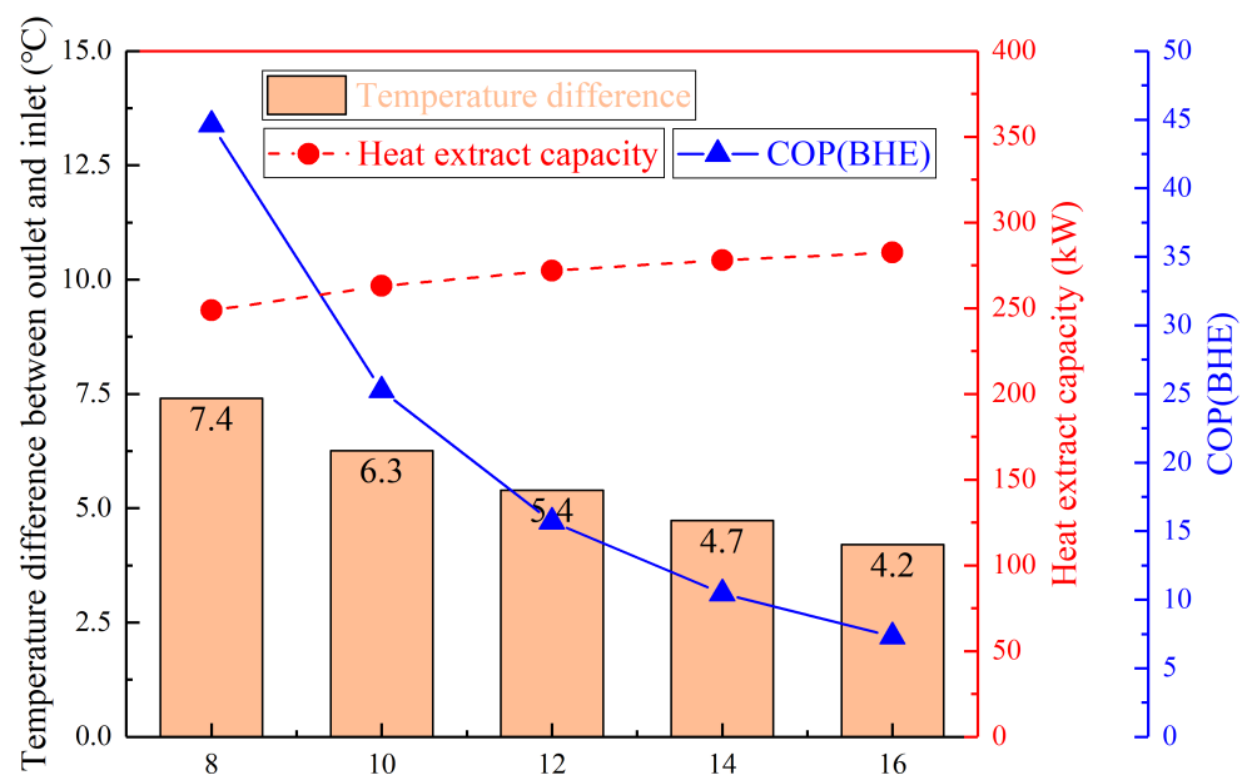

Fig. 8. Influence of mass flow rate on the temperature difference between outlet and inlet water, heat extract capacity, and $C O P_{B H E}$.

The mass flow rate would influence the flow resistance in the fluid channel and then affect the circulating pump power. Fig. 9 reveals the variation trends of corresponding water head, water pressure difference, and circulating pump power with the mass flow rate. These three parameters increase gradually with the increase of mass flow rate. A higher mass flow rate would lead to a higher flow resistance due to turbulence flow and cause a higher circulating pump power. For instance, the pressure difference between inlet and outlet is the highest $(2.5 \mathrm{Mpa})$ and its corresponding water head is $247 \mathrm{~m}$. In the meantime, the circulating pump power is $39 \mathrm{~kW}$ which could be calculated by Eq. 5 .

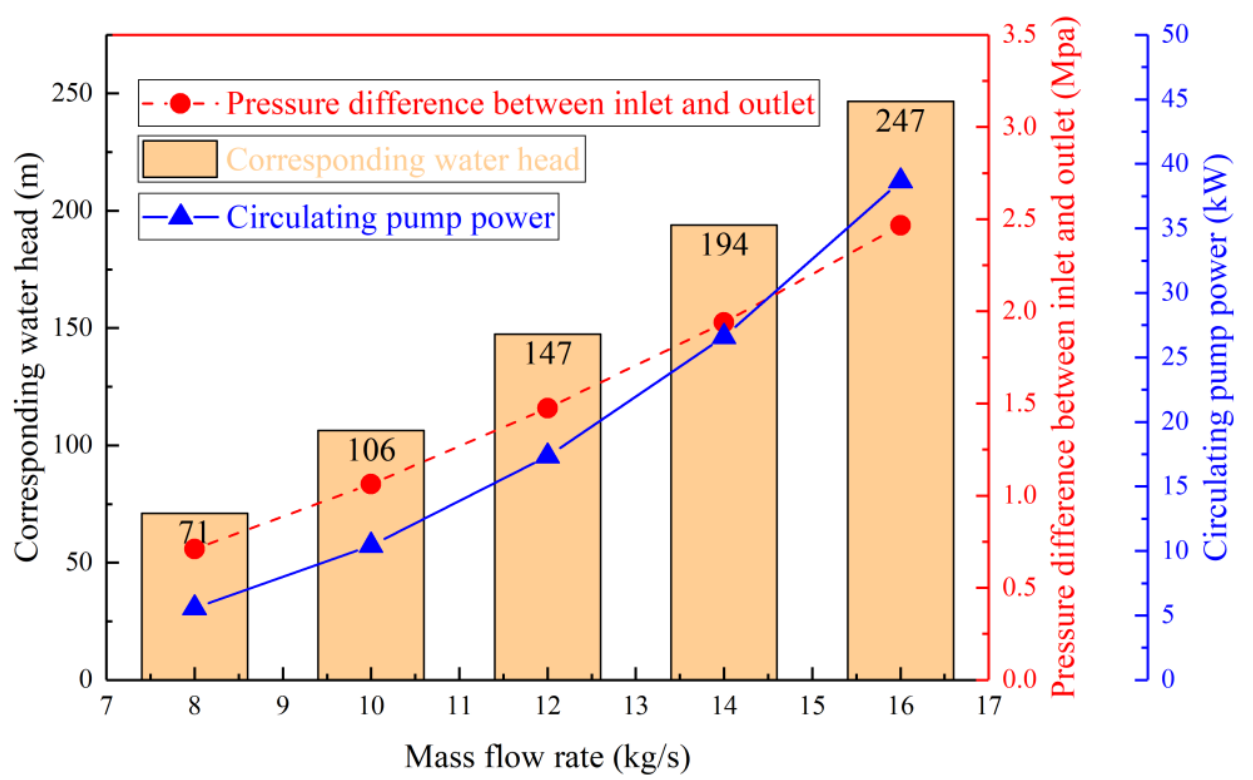

Fig. 9. Influence of mass flow rate on corresponding water head, water pressure difference between inlet and outlet, and circulating pump power. 


\subsection{Inlet water temperature}

Fig. 10 shows the influence of inlet water temperature on circulating water temperature at different positions. The circulating water mass flow rate is $12 \mathrm{~kg} / \mathrm{s}$ and the depth of BHE is $2500 \mathrm{~m}$. The outlet water temperatures are $13.2{ }^{\circ} \mathrm{C}, 17.3{ }^{\circ} \mathrm{C}, 21.3{ }^{\circ} \mathrm{C}, 25.4{ }^{\circ} \mathrm{C}, 29.4{ }^{\circ} \mathrm{C}, 33.5{ }^{\circ} \mathrm{C}$ when inlet water temperatures are $5{ }^{\circ} \mathrm{C}, 10{ }^{\circ} \mathrm{C}, 15^{\circ} \mathrm{C}, 20^{\circ} \mathrm{C}, 25^{\circ} \mathrm{C}, 30^{\circ} \mathrm{C}$, respectively. A higher inlet water temperature leads to a higher outlet water temperature, but the temperature difference between outlet and inlet water decreases with the increase of inlet water temperature. For instance, the outlet water temperature is $33.5^{\circ} \mathrm{C}$ when the inlet water temperature is $30^{\circ} \mathrm{C}$ while the temperature difference is the lowest $\left(3.5^{\circ} \mathrm{C}\right)$.

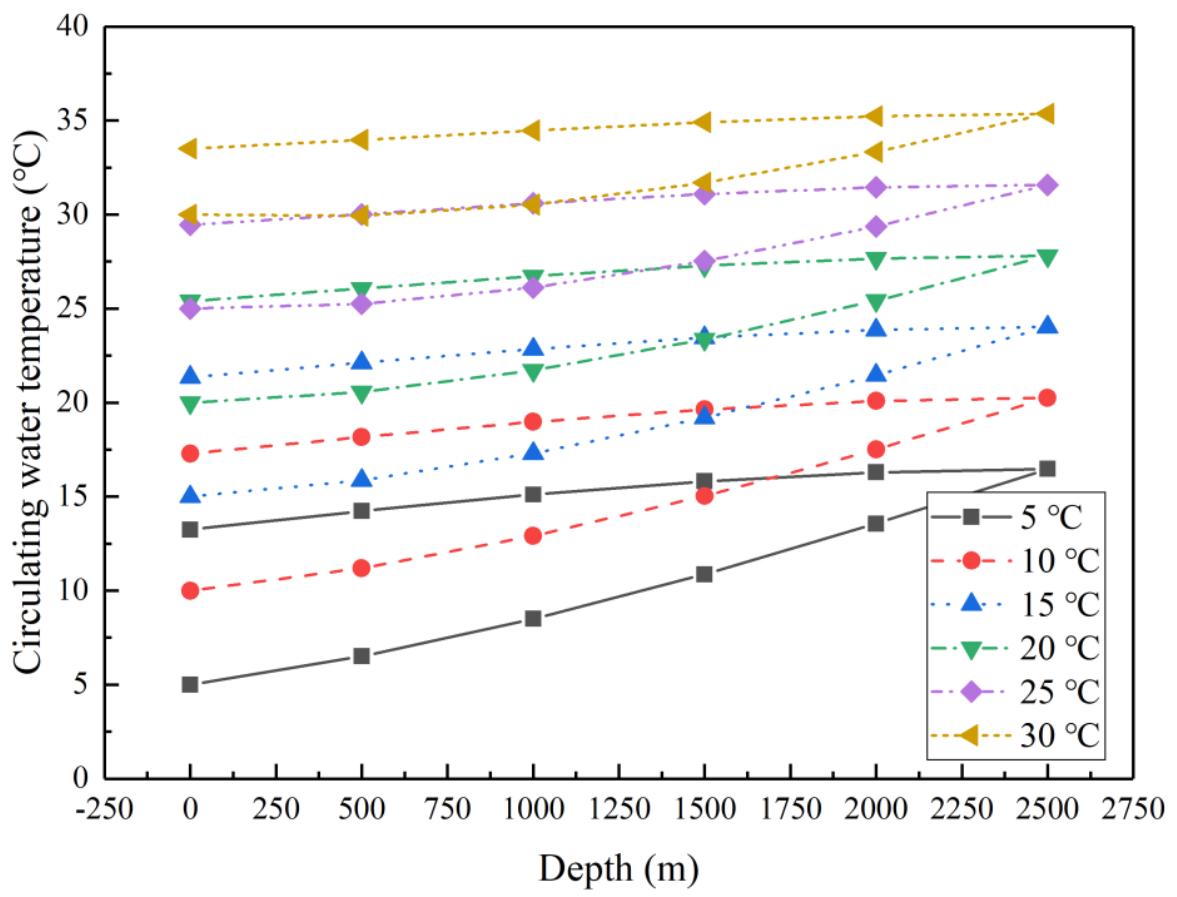

Fig. 10. Influence of inlet water temperature of BHE on circulating water temperature at different positions.

Fig. 11 shows the influence of the inlet water temperature of BHE on the temperature difference between outlet and inlet water, heat extract capacity, and $C O P_{B H E}$. Both heat extract capacity and BHE system COP decrease linearly with the increase of inlet water temperature. The heat extract capacity is $176.4 \mathrm{~kW}$ while the BHE system COP is 10.2 when the inlet water temperature is $30^{\circ} \mathrm{C}$. Furthermore, the temperature difference between outlet and inlet water decreases when the inlet water temperature increases. It is important to reveal the turning point when the temperature difference between the inlet and the outlet will be to $0{ }^{\circ} \mathrm{C}$ because it will reflect the uppertemperature limit of the inlet water. 


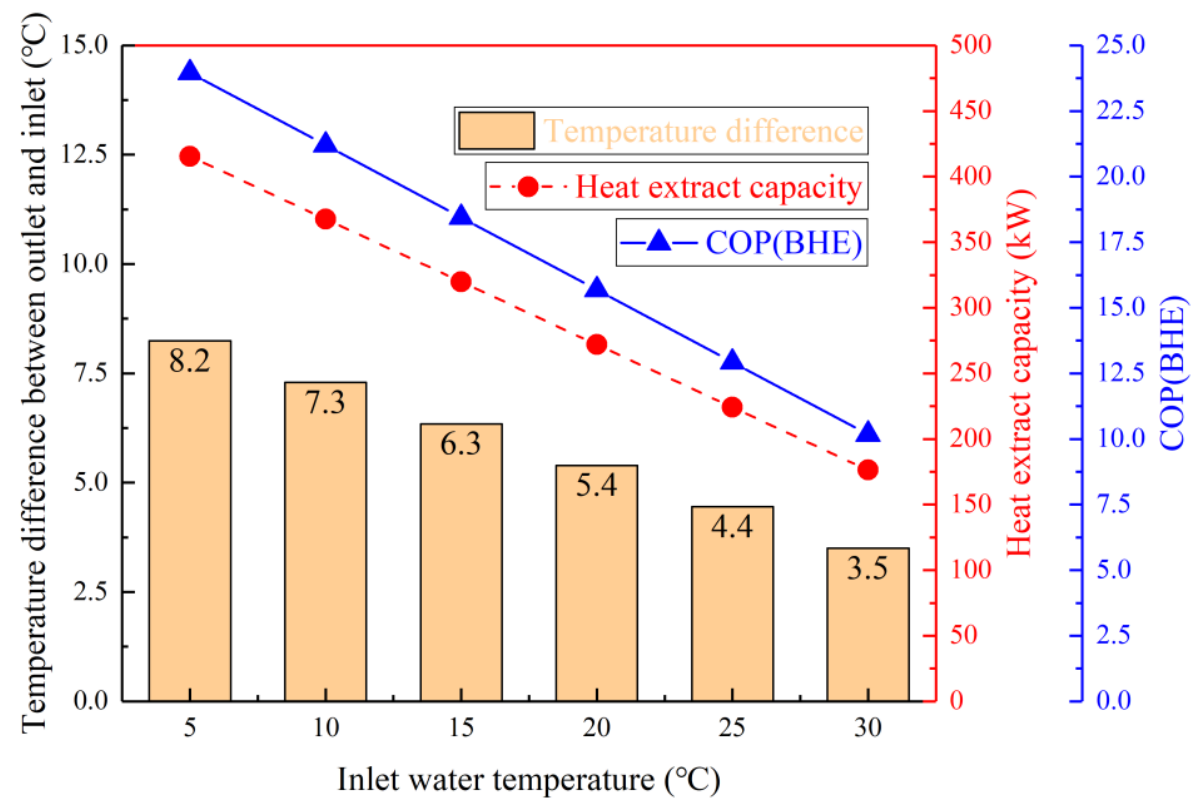

Fig. 11. Influence of inlet water temperature of BHE on the temperature difference between outlet and inlet water, heat extract capacity, and $C O P_{B H E}$.

The influence of inlet water temperature (over $40{ }^{\circ} \mathrm{C}$ ) on outlet water temperature has been further studied. As shown in Fig. 12, the outlet water temperature increases linearly while the temperature difference decreases linearly when inlet water temperature increases. Under this condition, the turning point occurs when the inlet water temperature is $48.5{ }^{\circ} \mathrm{C}$ which means the BHE would not produce heat any longer. Moreover, the circulating water will transfer heat to the ground when the inlet water temperature is over $48.5^{\circ} \mathrm{C}$.

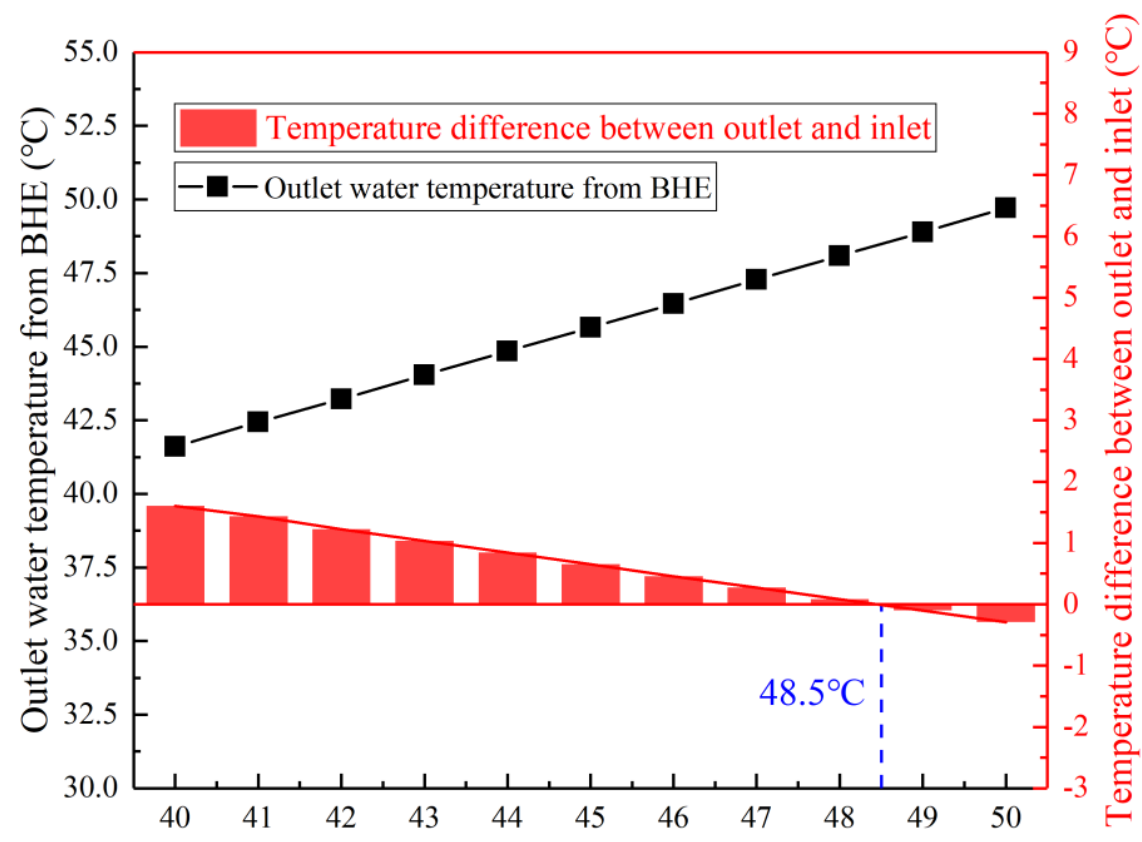

Inlet water temperature to $\mathrm{BHE}\left({ }^{\circ} \mathrm{C}\right)$

Fig. 12. Influence of inlet water temperature (over $40^{\circ} \mathrm{C}$ ) of BHE on outlet water temperature 


\subsection{Inner and outer pipes' diameters}

The inner and outer pipes diameter would affect the flow resistance in the fluid channel and then influence the thermal performance of BHE as well as the circulating pump power. Fig. 13(a) shows the influence of the inner pipe diameter on the temperature difference between outlet and inlet, heat extract capacity, and BHE system COP. The outer pipe diameter is $0.178 \mathrm{~m}$, circulating water mass flow rate is $12 \mathrm{~kg} / \mathrm{s}$, inlet water temperature to BHE is $20^{\circ} \mathrm{C}$, and depth of BHE is 2500 $\mathrm{m}$. The variation of outlet and inlet water temperature difference (about $0.2^{\circ} \mathrm{C}$ ) is not significant as well as heat extract capacity. However, the BHE system COP could reach the peak value (15.9) when the outer diameter of inner pipe is $0.11 \mathrm{~m}$. That is because the flow resistance under this condition is the lowest as shown in Fig. 13(b). In the meantime, the pressure difference between inlet and outlet is the lowest $(1.47 \mathrm{Mpa})$ which means the circulating pump power is also the lowest $(17.3 \mathrm{~kW})$ as well as the corresponding water head $(147.5 \mathrm{~m})$. Fig. 13 reveals that the inner pipe diameter would not influence the heat extract capacity of BHE significantly, but there is an optimal inner pipe diameter (outer diameter: $0.11 \mathrm{~m}$ ) to minimize flow resistance and pump power.

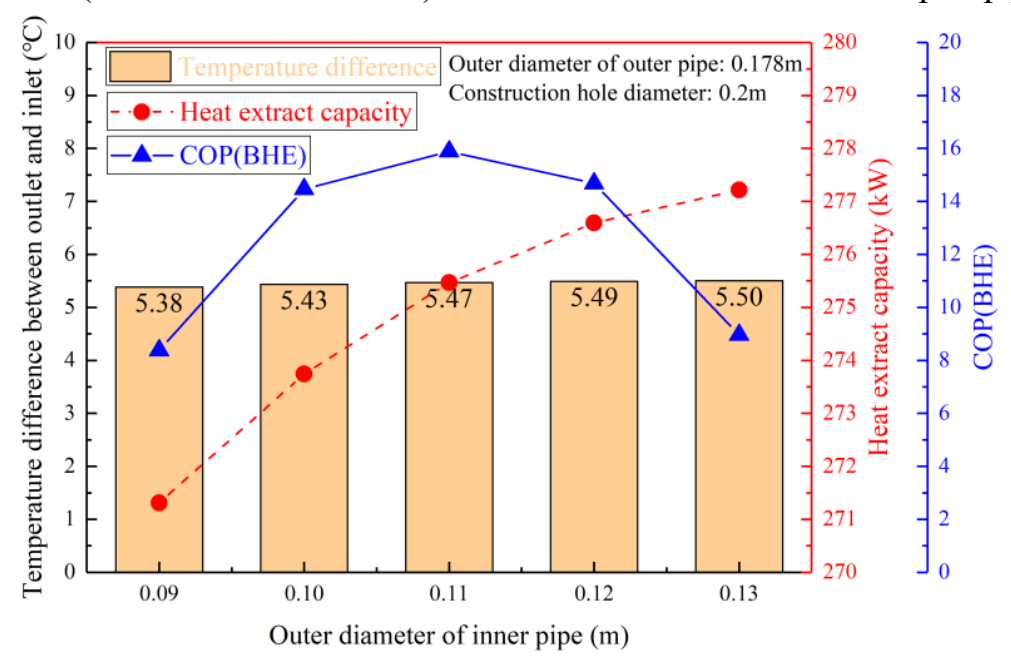

(a)

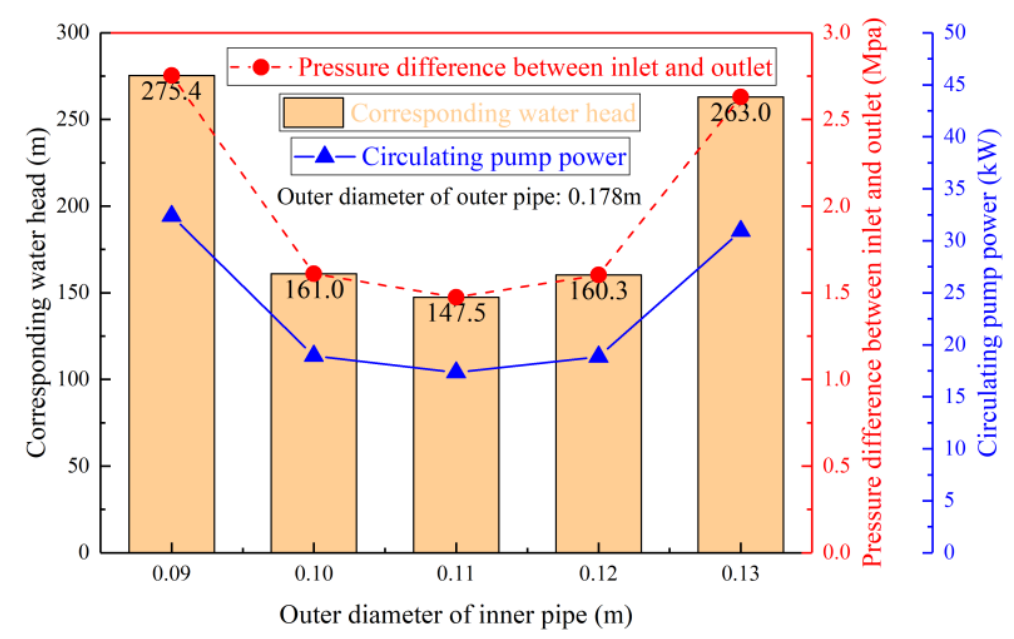

(b)

Fig. 13. (a) Influence of inner pipe diameter on the temperature difference between outlet and inlet, heat extract capacity, and $C O P_{B H E}$. (b) Influence of inner pipe diameter on corresponding water head, water pressure difference between inlet and outlet, and circulating pump power. 
The outer surface of the outer pipe is the main heat extract surface to absorb heat from the rock-soil. Thus, the outer piper diameter would not only influence the flow resistance but also the thermal performance of BHE. Thus, the influence of outer pipe diameter has been further studied under these working conditions: the inner pipe diameter is $0.11 \mathrm{~m}$, circulating water mass flow rate is $12 \mathrm{~kg} / \mathrm{s}$, inlet water temperature to BHE is $20^{\circ} \mathrm{C}$ and depth of BHE is $2500 \mathrm{~m}$. As shown in Fig. 14(a), the temperature difference between outlet and inlet and the heat extract capacity both increase gradually with the increase of outer pipe diameter while the BHE system COP increases rapidly at first and then increase smoothly. The outlet water temperature could reach $28.3{ }^{\circ} \mathrm{C}$ when the outer pipe diameter is $0.378 \mathrm{~m}$. Fig. 14(b) shows that a larger outer pipe diameter would reduce the flow resistance, thus, the circulating pump power, as well as corresponding water head, are lower under a larger outer pipe diameter. For instance, the pressure difference between inlet and outlet is the lowest $(0.78 \mathrm{Mpa})$ while the pump power is $9.2 \mathrm{~kW}$. Therefore, a larger outer pipe diameter has a larger heat transfer surface area which is better for the circulating water to extract heat from the rock-soil. Moreover, a larger outer pipe diameter could also reduce the flow resistance and circulating pump power.

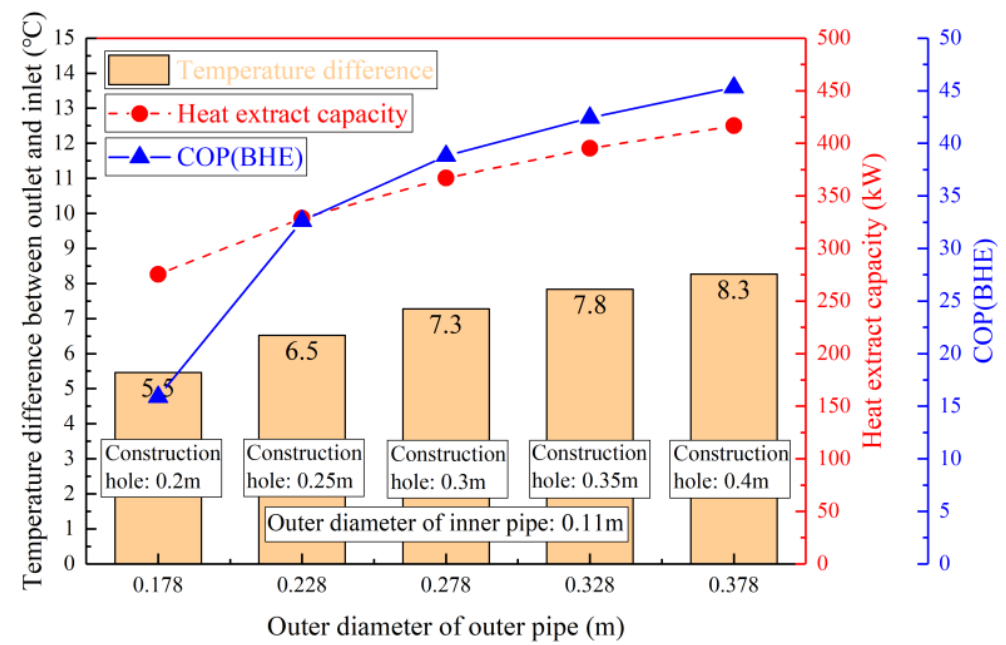

(a)

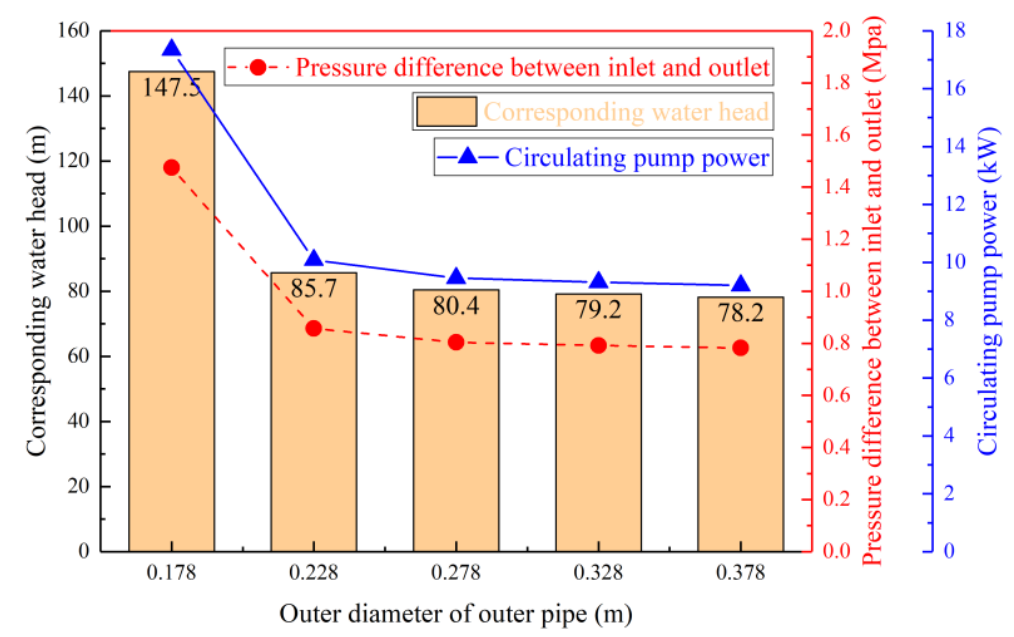

(b)

Fig. 14. (a) Influence of outer pipe diameter on the temperature difference between outlet and inlet, heat extract capacity, and $C O P_{B H E}$. (b) Influence of outer pipe diameter on corresponding 
water head, water pressure difference between inlet and outlet, and circulating pump power.

\subsection{Thermal effect radius}

Thermal effect radius is an important parameter to determine the arrangement of several borehole heat exchangers. The heat extract capacity would be degraded and the recovery of ground temperature would be affected if the BHEs are placed too closely. Fig. 15 reveals the variation trends of the thermal effect radius of BHE at different depths. The simulation results show that the thermal effect radius would decrease at first when the depth is less than $750 \mathrm{~m}$ and then increase when the depth is bigger than $750 \mathrm{~m}$. That is because when circulating water flow through the outer pipe, it will be heated by the rock-soil and the temperature difference between inlet and outlet water would decrease when the depth is less than $750 \mathrm{~m}$. The circulating water will extract less heat from the rock-soil and cause a smaller thermal effect radius. The biggest thermal effect radius is less than 8 $\mathrm{m}$ which means if the distance of two BHEs is larger than $16 \mathrm{~m}$, the effect between the two BHEs could be neglected.

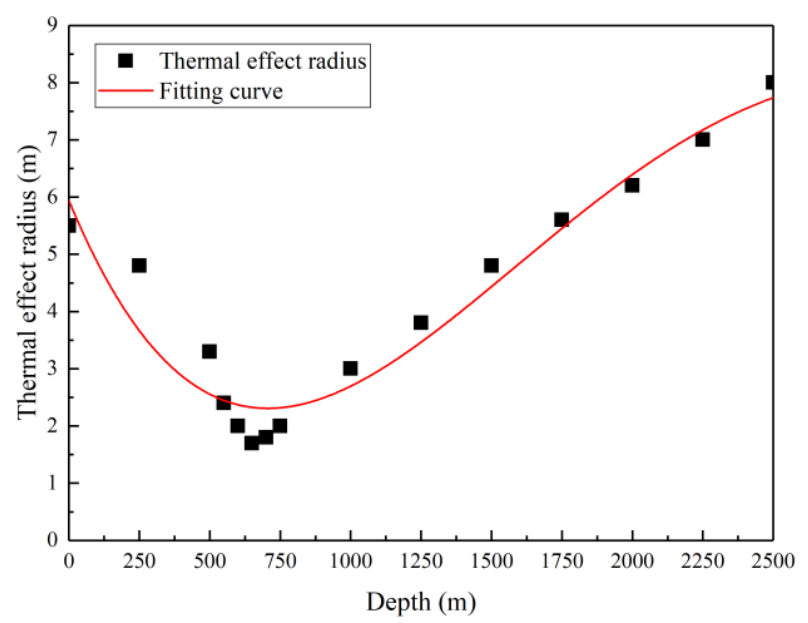

Fig. 15. Thermal effect radius of BHE at different depths.

\subsection{Solar radiation intensity}

Fig. 16 shows the influence of solar radiation intensity varying from $200 \mathrm{~W} / \mathrm{m}^{2}$ to $1000 \mathrm{~W} / \mathrm{m}^{2}$ on circulating water temperature, heating area, and solar fraction. The working conditions are: area of PV/T module is $1000 \mathrm{~m}^{2}$; depth of BHE is $2500 \mathrm{~m}$; mass flow rate of circulating water is $12 \mathrm{~kg} / \mathrm{s}$ and ambient temperature is $10{ }^{\circ} \mathrm{C}$. The inlet water temperature is $30{ }^{\circ} \mathrm{C}$ while the temperature difference between inlet and outlet circulating water is $3.5^{\circ} \mathrm{C}$, thus, the outlet water temperature is $33.5^{\circ} \mathrm{C}$. The temperature range of circulating water for heating applications is from $35^{\circ} \mathrm{C}$ to $45^{\circ} \mathrm{C}$ while $33.5^{\circ} \mathrm{C}$ is not high enough for residential heating. The solar assisted PV/T heat pump system is adopted to further heat the circulating water. The temperature increments by the PV/T heat pump as well as the heating COP increase with the increase of solar radiation intensity. Solar fraction is an important parameter to evaluate the contribution of solar energy. The solar assisted PV/T heat pump system could increase $3.2^{\circ} \mathrm{C}$ of the outlet water temperature from BHE when solar radiation intensity is $200 \mathrm{~W} / \mathrm{m}^{2}$ and the circulating water could be heated up to $36.7^{\circ} \mathrm{C}$ while the solar fraction 
is $47.5 \%$. The temperature increment by the $\mathrm{PV} / \mathrm{T}$ heat pump could reach $7.3{ }^{\circ} \mathrm{C}$ and the outlet water to users could be heated up to $40.8^{\circ} \mathrm{C}$ if the solar radiation intensity is $600 \mathrm{~W} / \mathrm{m}^{2}$. In this case, the solar fraction is $67.5 \%$ while the heating COP of this hybrid system is 7.4 . The borehole heat exchanger coupled with a solar assisted PV/T heat pump heating system is thus a promising technology for residential heating due to high efficiency, low energy consumption, and environmental-friendly.

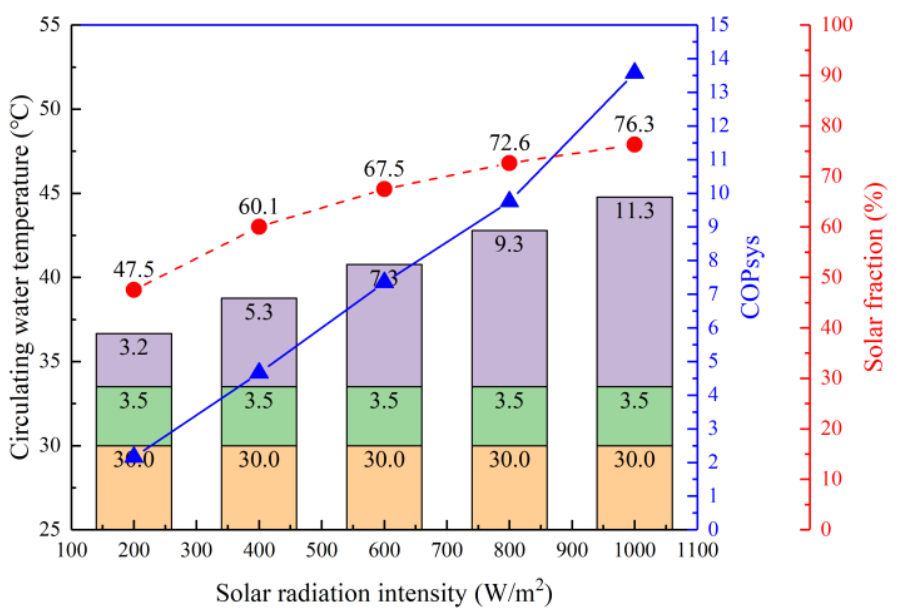
\begin{tabular}{l}
\hline Temperature increment by $\mathrm{PV} / \mathrm{T}$ heat pump \\
\hline Temperature increment by $\mathrm{BHE}$
\end{tabular} Inlet water temperature of BHE

\section{- - Solar fraction}

$-\boldsymbol{\Delta}$-COPsys

Area of PV/T module: $1000 \mathrm{~m}^{2}$

Depth of BHE: $2500 \mathrm{~m}$

Mass flow rate of circulating water: $12 \mathrm{~kg} / \mathrm{s}$

Inlet water temperature to BHE: $30^{\circ} \mathrm{C}$

Ambient temperature: $10^{\circ} \mathrm{C}$

Fig. 16. Influence of solar radiation intensity on circulating water temperature, heating COP of this hybrid system, and solar fraction.

One merit of the PV/T module is that it could produce electricity and heat simultaneously, thus, the electricity generated by PV panels could be used for system consumption including compressor and pump. The pump power using in this hybrid system is $17.3 \mathrm{~kW}$ when the mass flow rate is 12 $\mathrm{kg} / \mathrm{s}$ while the compressor power is simulated through the mathematical model. The influence of solar radiation intensity on output power to grid, heating power produced by BHE, heating power produced by heat pump, and overall heating power has shown in Fig. 17. The output power to grid, heating power produced by solar assisted PV/T heat pump, and overall heating power increase linearly with the increase of solar radiation intensity. The electricity generated by PV panels could meet the energy consumption demand of this hybrid system when solar radiation intensity exceeds $600 \mathrm{~W} / \mathrm{m}^{2}$.

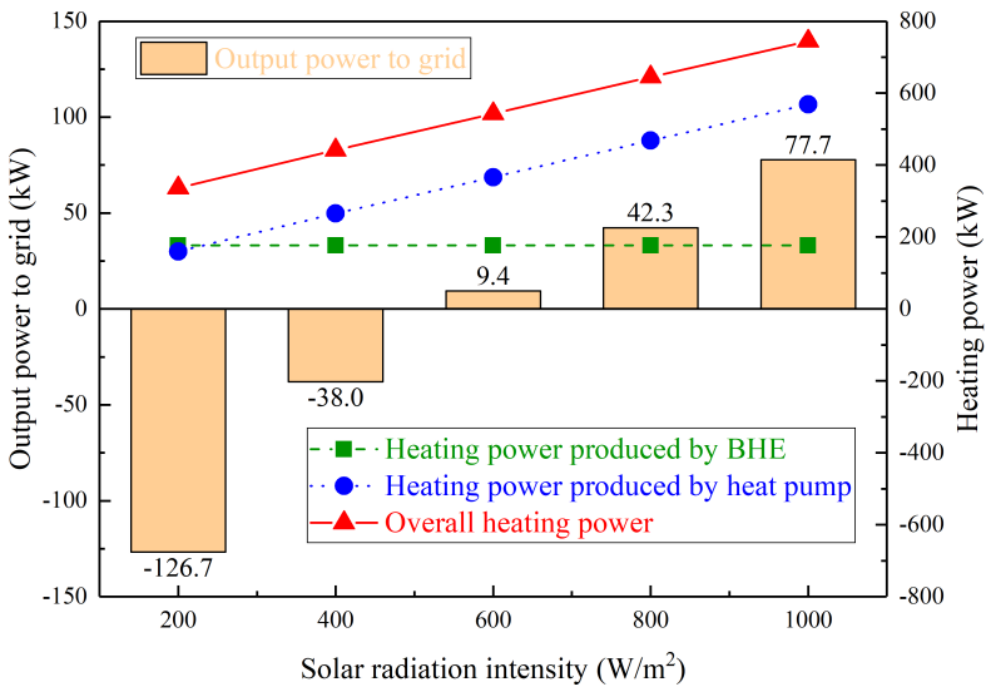


Fig. 17. Influence of solar radiation intensity on output power to grid, heating power produced by BHE, heating power produced by heat pump, and overall heating power.

\title{
5.6 Area of PV/T module
}

Fig. 18 presents the influence of the area of PV/T module varying from $200 \mathrm{~m}^{2}$ to $2000 \mathrm{~m}^{2}$ on circulating water temperature, heating area, and solar fraction. The working conditions are given: solar radiation intensity is $600 \mathrm{~W} / \mathrm{m}^{2}$; the depth of BHE is $2500 \mathrm{~m}$; the mass flow rate of circulating water is $12 \mathrm{~kg} / \mathrm{s}$ and the ambient temperature is $10{ }^{\circ} \mathrm{C}$. The temperature increment by PV/T heat pump increases linearly with the increase of the area of PV/T module due to a larger solar absorption surface. The heating COP of this hybrid system decreases and solar fraction increases with the increase of $\mathrm{PV} / \mathrm{T}$ area. The outlet water temperature from this hybrid system is $35^{\circ} \mathrm{C}$ which is in the temperature range for residential heating when the area of PV/T module is $200 \mathrm{~m}^{2}$. The solar fraction could reach $80.6 \%$ when the area of $\mathrm{PV} / \mathrm{T}$ module is $2000 \mathrm{~m}^{2}$. In the meantime, the outlet water temperature could reach $48{ }^{\circ} \mathrm{C}$. The heating COP of this hybrid system decreases from 8.7 to 7.0 when $\mathrm{PV} / \mathrm{T}$ area varies from $200 \mathrm{~m}^{2}$ to $2000 \mathrm{~m}^{2}$.

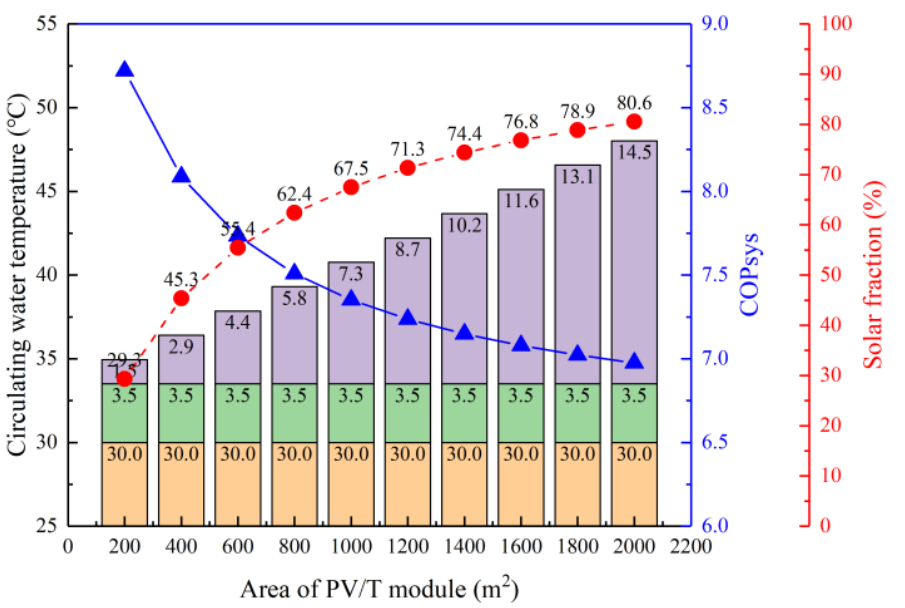

\author{
Temperature increment by PV/T heat pump \\ Temperature increment by BHE \\ Inlet water temperature of BHE \\ - - Solar fraction \\ - $\mathbf{\Delta - C O P s y s}$ \\ Solar radiation intensity: $600 \mathrm{~W} / \mathrm{m}^{2}$ \\ Depth of BHE: $2500 \mathrm{~m}$ \\ Mass flow rate of circulating water: $12 \mathrm{~kg} / \mathrm{s}$ \\ Inlet water temperature to BHE: $30^{\circ} \mathrm{C}$ \\ Ambient temperature: $10^{\circ} \mathrm{C}$
}

Fig. 18. Influence of area of $\mathrm{PV} / \mathrm{T}$ module on circulating water temperature, heating $\mathrm{COP}$ of this hybrid system, and solar fraction.

The influence of the area of PV/T module on output power to grid, heating power produced by BHE, heating power produced by heat pump, and overall heating power has shown in Fig. 19 and the solar radiation intensity is $600 \mathrm{~W} / \mathrm{m}^{2}$. The variation curves show the same linearly increasing trend as in Fig. 18. The maximum overall heating power is $908 \mathrm{~kW}$ while $80.6 \%$ of it produced by the heat pump when the area of PV/T module is $2000 \mathrm{~m}^{2}$. The output power to grid exceeds zero when PV/T module's area over $650 \mathrm{~m}^{2}$ which means the electricity produced by PV panels could meet system demand. Moreover, the surplus power could be sold to the electrical grid to create economic benefits for users. 


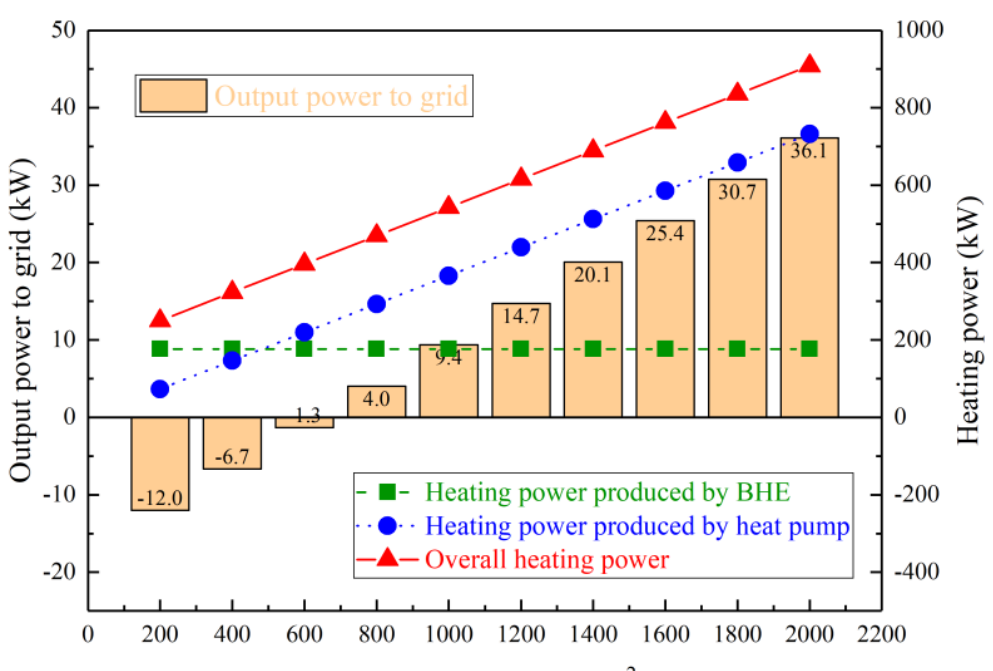

Fig. 19. Influence of area of $\mathrm{PV} / \mathrm{T}$ module on output power to grid, heating power produced by BHE, heating power produced by heat pump, and overall heating power.

\subsection{Feasibility analysis}

A comparison between a single BHE heating system and a BHE coupled with solar PV/T heat pump heating system should be conducted to show the feasibility and merits of this hybrid system. Thus, the performance comparison in detail has been listed in Table. 8 under typical working conditions which have shown in Table. 7.

Table. 7. Typical working conditions.

\begin{tabular}{llll}
\hline Parameters & Nomenclature & Value & Unit \\
\hline Depth of BHE & $H$ & 2500 & $\mathrm{~m}$ \\
Mass flow rate of circulating water & $m$ & 12 & $\mathrm{~kg} / \mathrm{s}$ \\
Inlet water temperature to BHE & $T_{i}$ & 30 & ${ }^{\circ} \mathrm{C}$ \\
Area of PV/T module & $A_{P V / T}$ & 1000 & $\mathrm{~m}^{2}$ \\
Solar radiation intensity & $I$ & 600 & $\mathrm{~W} / \mathrm{m}^{2}$ \\
Ambient temperature & $T_{a}$ & 10 & ${ }^{\circ} \mathrm{C}$ \\
Ground surface temperature & $T_{u p}$ & 10 & ${ }^{\circ} \mathrm{C}$ \\
Wind velocity & $v_{w}$ & 1.5 & $\mathrm{~m} / \mathrm{s}$ \\
\hline
\end{tabular}

Table. 8 presents the comparison results between a single BHE heating system and a BHE coupled with solar PV/T heat pump heating system. The heating power of this hybrid system is 542 $\mathrm{kW}$ which is about 3 times of a single BHE system. The outlet water temperature form BHE could increase $7.3{ }^{\circ} \mathrm{C}$ after heating by solar assisted PV/T heat pump. This hybrid system would consume $56.4 \mathrm{~kW}$ electricity to drive the compressor, however, the PV/T module could produce $83.1 \mathrm{~kW}$ electricity through PV panels which could meet the energy demand of the compressor and pump. Thus, this hybrid system could realize self-operation under this condition.

Table. 8. Performance comparison between single BHE heating system and BHE coupled with 


\begin{tabular}{lll}
\hline Parameters & $\begin{array}{l}\text { Single BHE heating } \\
\text { system }\end{array}$ & $\begin{array}{l}\text { BHE coupled with PV/T } \\
\text { heat pump heating system }\end{array}$ \\
\hline Heating power $(\mathrm{kW})$ & 176.4 & 542.3 \\
Outlet water temperature $\left({ }^{\circ} \mathrm{C}\right)$ & 33.5 & 40.8 \\
Circulating pump power $(\mathrm{kW})$ & 17.3 & 17.3 \\
Compressor power $(\mathrm{kW})$ & 0 & 56.4 \\
Total energy consumption power $(\mathrm{kW})$ & 17.3 & 73.7 \\
Electricity generation power $(\mathrm{kW})$ & 0 & 83.1 \\
Heating COP $(-)$ & 10.2 & 7.4 \\
\hline
\end{tabular}

600

601

602

603

604

605

606

607

608

609

610

611

612

613

Fig. 20 shows the contribution ratio of BHE, solar energy, and heat pump in the residential heating power of this hybrid system. The total heating power produced by this hybrid system is 542 $\mathrm{kW}$, the heating power produced by solar energy accounts for $57 \%$ of it due to the absorption heat from PV/T module. The heating power produced by BHE and the heating power produced by the heat pump are $33 \%$ and $10 \%$ of total heating power, respectively. Hence, this residential heating system using BHE coupled with a solar assisted $\mathrm{PV} / \mathrm{T}$ heat pump has a significant improvement in thermal performance compared with a single BHE heating system. Therefore, the combination of a borehole heat exchanger and the solar assisted PV/T heat pump has broad application prospect and potential usage in stable, comfortable, low-energy consumption, and environmental-friendly residential heating.

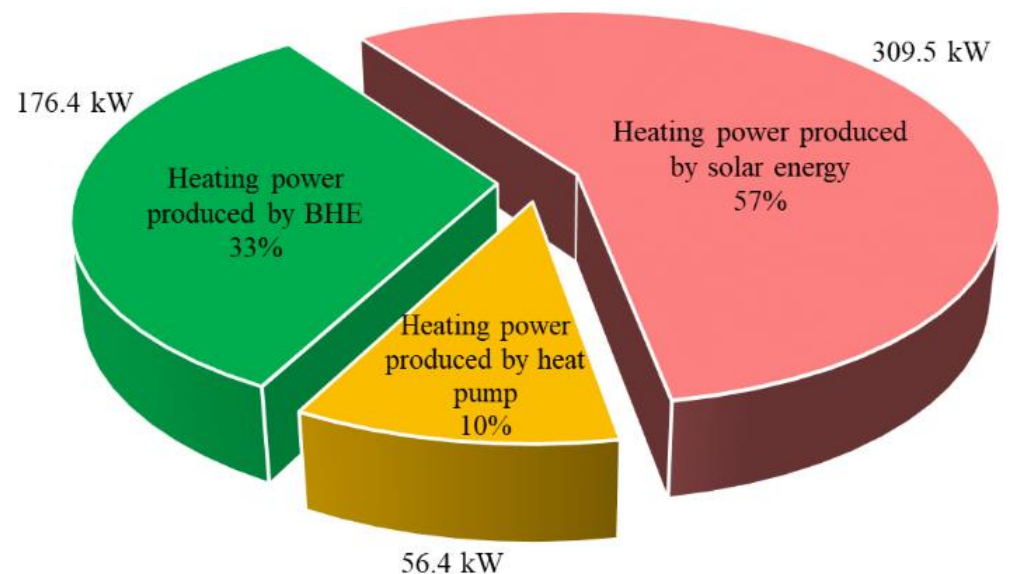

Fig. 20. Contribution ratio of BHE, solar energy, and heat pump in residential heating power.

\section{Conclusion}

The performance analysis of a residential heating system using a borehole heat exchanger coupled with a solar assisted PV/T heat pump has been conducted. It is aiming to optimize the performance and demonstrates the merits of this hybrid system. The effects of the system's physical structure parameters and operating conditions have been also numerically investigated. The main conclusions can be drawn as follows:

(1) The outlet water temperature as well as the BHE system COP decrease and the heat extract capacity as well as flow resistance increase with the increase of mass flow rate. The maximum heat extract capacity is $282.5 \mathrm{~kW}$ while the BHE system COP is 7.3 when the mass flow rate is $16 \mathrm{~kg} / \mathrm{s}$. In addition, the circulating water could not extract heat from BHE if the inlet water temperature 
exceeds $48.5^{\circ} \mathrm{C}$ when the mass flow rate is $12 \mathrm{~kg} / \mathrm{s}$.

(2) The inner pipe diameter would not influence the heat extract capacity of BHE significantly, but there is an optimal inner pipe diameter (outer diameter: $0.11 \mathrm{~m}$ ) to minimize the flow resistance $(1.47 \mathrm{Mpa})$ and the pump power $(17.3 \mathrm{~kW})$ when the outer pipe diameter is $0.178 \mathrm{~m}$. Larger outer pipe diameter is better for the circulating water to extract heat from the rock-soil and it could also reduce the flow resistance and the circulating pump power.

(3) The maximum outlet temperature could reach $40.8{ }^{\circ} \mathrm{C}$ while the solar fraction is $67.5 \%$ when the area of PV/T module is $1000 \mathrm{~m}^{2}$ and solar irradiation is $600 \mathrm{~W} / \mathrm{m}^{2}$. In addition, the electricity generated by the PV panels could meet the system's energy consumption demand when solar irradiation exceeds $600 \mathrm{~W} / \mathrm{m}^{2}$ or PV/T module's area is larger than $650 \mathrm{~m}^{2}$. Moreover, the heating COP of this hybrid system could reach 7.4 which is higher than that of a conventional heating system.

Therefore, the analysis of the above-mentioned parameters could be used to design and optimize the residential heating system using borehole heat exchanger coupled with a solar assisted $\mathrm{PV} / \mathrm{T}$ heat pump.

\section{Acknowledgements}

This research work is funded by the International Research Cooperation Program of Shanghai (Grant No. 18160710500).

\section{Nomenclature:}

\section{Symbols}

$A$

$F^{\prime}$

$H$

$h$

U

V

$r$

$d$

$T$

I

$Q$

W

$v$

$k$

$m$

$n$

$C p$

$R$

644

645 $\operatorname{area}\left(\mathrm{m}^{2}\right)$

unmodified efficiency factor (-)

depth of borehole heat exchanger $(\mathrm{m})$

heat transfer coefficient $\left(\mathrm{W} / \mathrm{m}^{2} \cdot{ }^{\circ} \mathrm{C}\right)$

heat loss coefficient $\left(\mathrm{W} / \mathrm{m}^{2 .}{ }^{\circ} \mathrm{C}\right)$

volume flow rate $\left(\mathrm{m}^{3} / \mathrm{h}\right)$

radius (m)

diameter $(\mathrm{m})$

temperature $(\mathrm{K})$

solar radiation intensity $\left(\mathrm{W} / \mathrm{m}^{2}\right)$

heat transfer rate $(\mathrm{W})$

power (W)

velocity $(\mathrm{m} / \mathrm{s})$

thermal conductivity $\left(\mathrm{W} / \mathrm{m} \cdot{ }^{\circ} \mathrm{C}\right)$

mass flow rate $(\mathrm{kg} / \mathrm{s})$

numbers (-)

specific heat at constant pressure $\left(\mathrm{kJ} / \mathrm{kg} \cdot{ }^{\circ} \mathrm{C}\right)$

thermal resistance $\left(\mathrm{m} \cdot{ }^{\circ} \mathrm{C} / \mathrm{W}\right)$

\section{Greek symbols}

thickness (m) 


$\begin{array}{lll} & \tau & \text { transmittance }(-) \\ a & \text { absorption ratios (-) } \\ \beta & \text { packing factor (-) } \\ \varepsilon & \text { emissivity }(-) \\ \eta & \text { efficiency }(-) \\ \rho & \text { density }\left(\mathrm{kg} / \mathrm{m}^{3}\right) \\ 646 & & \\ \text { Subscripts } & \\ p & \text { PV panels } \\ \text { pump } & \text { pump } \\ \text { heating } & \text { residential heating } \\ e & \text { electrical } \\ c & \text { PV-glazing cover } \\ \text { ref } & \text { refrigerant } \\ \text { res } & \text { flow resistance } \\ c v & \text { convection } \\ c d & \text { conduction } \\ r d & \text { radiation } \\ a & \text { ambient } \\ L & \text { lost } \\ u & \text { useful } \\ f & \text { fluid } \\ \text { Tot } & \text { total } \\ & \\ & \end{array}$

\section{References:}

649 [1] L. Pietrosemoli, C. Rodríguez-Monroy, The Venezuelan energy crisis: Renewable energies in 650 the transition towards sustainability, Renewable and Sustainable Energy Reviews 105 (2019) 415651426.

652 [2] Y. Yuan, X. Cao, L. Sun, B. Lei, N. Yu, Ground source heat pump system: A review of simulation 653 in China, Renewable and Sustainable Energy Reviews 16(9) (2012) 6814-6822.

654 [3] J.W. Lund, D.H. Freeston, T.L. Boyd, Direct utilization of geothermal energy 2010 worldwide 655 review, Geothermics 40(3) (2011) 159-180.

656 [4] E.D. Kerme, A.S. Fung, Heat transfer simulation, analysis and performance study of single U657 tube borehole heat exchanger, Renewable Energy 145 (2020) 1430-1448.

658 [5] E. Greber, T. Grünenfelder, B. Keller, R. Wyss, Die Geothermie-Bohrung Weggis, Kanton 659 Luzern, Bull. Schweiz. Ver. Petroleum-Geol. u. -Ing. 61 (1994) 17-43.

660 [6] X. Bu, W. Ma, H. Li, Geothermal energy production utilizing abandoned oil and gas wells, 661 Renewable Energy 41 (2012) 80-85.

662 [7] A. Sapinska-Sliwa, M. Rosen, A. Gonet, T. Sliwa, Deep Borehole Heat Exchangers - A 663 Conceptual and Comparative Review, International Journal of Air-Conditioning and Refrigeration $66424(2015)$.

665 [8] X. Hu, J. Banks, L. Wu, W.V. Liu, Numerical modeling of a coaxial borehole heat exchanger to 666 exploit geothermal energy from abandoned petroleum wells in Hinton, Alberta, Renewable Energy $667148(2020) 1110-1123$. 
[9] Q. Zhao, B. Chen, F. Liu, Study on the thermal performance of several types of energy pile ground heat exchangers: U-shaped, W-shaped and spiral-shaped, Energy and Buildings 133 (2016) 335-344.

[10] L. Zhu, S. Chen, Y. Yang, Y. Sun, Transient heat transfer performance of a vertical double Utube borehole heat exchanger under different operation conditions, Renewable Energy 131 (2019) 494-505.

[11] A. Pan, L. Lu, P. Cui, L. Jia, A new analytical heat transfer model for deep borehole heat exchangers with coaxial tubes, International Journal of Heat and Mass Transfer 141 (2019) 10561065 .

[12] T. Renaud, P. Verdin, G. Falcone, Numerical simulation of a Deep Borehole Heat Exchanger in the Krafla geothermal system, International Journal of Heat and Mass Transfer 143 (2019).

[13] Y. Luo, H. Guo, F. Meggers, L. Zhang, Deep coaxial borehole heat exchanger: Analytical modeling and thermal analysis, Energy 185 (2019) 1298-1313.

[14] L. Fang, N. Diao, Z. Shao, K. Zhu, Z. Fang, A computationally efficient numerical model for heat transfer simulation of deep borehole heat exchangers, Energy and Buildings 167 (2018) 79-88. [15] J. Liu, F. Wang, W. Cai, Z. Wang, C. Li, Numerical investigation on the effects of geological parameters and layered subsurface on the thermal performance of medium-deep borehole heat exchanger, Renewable Energy 149 (2020) 384-399.

[16] X. Song, G. Wang, Y. Shi, R. Li, Z. Xu, R. Zheng, Y. Wang, J. Li, Numerical analysis of heat extraction performance of a deep coaxial borehole heat exchanger geothermal system, Energy 164 (2018) 1298-1310.

[17] I. Sarbu, C. Sebarchievici, General review of ground-source heat pump systems for heating and cooling of buildings, Energy and Buildings 70 (2014) 441-454.

[18] Z. Wang, F. Wang, J. Liu, Z. Ma, E. Han, M. Song, Field test and numerical investigation on the heat transfer characteristics and optimal design of the heat exchangers of a deep borehole ground source heat pump system, Energy Conversion and Management 153 (2017) 603-615.

[19] G. Nouri, Y. Noorollahi, H. Yousefi, Solar assisted ground source heat pump systems - A review, Applied Thermal Engineering 163 (2019).

[20] O. Ozgener, A. Hepbasli, Experimental performance analysis of a solar assisted ground-source heat pump greenhouse heating system, Energy and Buildings 37(1) (2005) 101-110.

[21] O. Ozgener, A. Hepbasli, Experimental investigation of the performance of a solar-assisted ground-source heat pump system for greenhouse heating, International Journal of Energy Research 29 (2005) 217-231.

[22] E. Wang, A.S. Fung, C. Qi, W.H. Leong, Performance prediction of a hybrid solar groundsource heat pump system, Energy and Buildings 47 (2012) 600-611.

[23] S. Huang, W. Zuo, H. Lu, C. Liang, X. Zhang, Performance comparison of a heating tower heat pump and an air-source heat pump: A comprehensive modeling and simulation study, Energy Conversion and Management 180 (2019) 1039-1054.

[24] J. P. Hartnett, W. M. Rohsenow, Handbook of Heat Transfer, 1973.

[25] J. Yao, H. Xu, Y. Dai, M. Huang, Performance analysis of solar assisted heat pump coupled with build-in PCM heat storage based on PV/T panel, Solar Energy 197 (2020) 279-291.

[26] F. Huide, Z. Xuxin, M. Lei, Z. Tao, W. Qixing, S. Hongyuan, A comparative study on three types of solar utilization technologies for buildings: Photovoltaic, solar thermal and hybrid photovoltaic/thermal systems, Energy Conversion and Management 140 (2017) 1-13. 
[27] J. Duffie, W.A. Beckman, W. Worek, Solar Engineering of Thermal Process, Journal of Solar Energy Engineering-transactions of The Asme - J SOL ENERGY ENG 116 (1994).

714 [28] Y. Ma, Analysis of Electrical Efficiency for Positive Displacement Refrigerant Compressor, 715 Journal of Refrigeration (2013). 